\title{
Caracterização, impactos e gestão de sítios arqueológicos do vale do rio Pitangui, Ponta Grossa, região dos Campos Gerais do Paraná
}

\author{
Characterization, impacts and management of archaeological sites in the Pitangui river \\ valley, Ponta Grossa, Campos Gerais region, Paraná State
}

\begin{abstract}
Henrique Simão Pontes
Geógrafo e Doutor em Geologia Ambiental, Departamento de Geociências, Universidade Estadual de Ponta Grossa (UEPG) e Grupo Universitário de Pesquisas Espeleológicas (GUPE), Brasil

henriquegeografo@gmail.com
\end{abstract}

Alessandro Giulliano Chagas Silva
Geógrafo, Projeto Arqueotrekking e Grupo Universitário de
Pesquisas Espeleológicas (GUPE), Brasil
arqueotrekking@gmail.com

Laís Luana Massuqueto Geógrafa e Doutora em Geologia Ambiental, Grupo Universitário de Pesquisas Espeleológicas (GUPE), Brasil lais.massuqueto@gmail.com

\begin{abstract}
Resumo
A presente pesquisa mostra um estudo sobre os sítios arqueológicos do vale do rio Pitangui, no município de Ponta Grossa, estado do Paraná. Como resultados, medidas de gestão destes sítios arqueológicos são apresentadas, a fim de harmonizar os diferentes interesses de uso com a conservação deste patrimônio. Os abrigos são conceituados neste estudo como cavidades naturais subterrâneas, com seus regimes de uso e proteção também vinculados à legislação espeleológica brasileira. $\mathrm{Na}$ área pesquisada foram caracterizados quatro abrigos que constituem sítios arqueológicos distintos, nominados de Abrigo Pitangui I, Abrigo Pitangui II, Abrigo Vale dos Escoteiros e Abrigo Usina São Jorge. Nesses sítios ocorrem pinturas rupestres associadas às tradições arqueológicas Planalto e Geométrica. Nestas cavidades naturais subterrâneas foram identificados impactos negativos graves, sobretudo devido à vulnerabilidade destes locais por conta de: a) queimadas; b) pichações (rabiscos) sobre as pinturas rupestres; c) quebra proposital de painéis com gravuras; d) intensa visitação turística; e) processos erosivos causados por trilhas de motocross e; f) descaracterização da vegetação nativa no entorno dos abrigos. Conclui-se que as principais medidas de gestão destes sítios arqueológicos envolvem a criação ou ampliação de áreas protegidas (principalmente unidades de conservação de proteção integral ou tombamento), fiscalização constante, manutenção (sobretudo para evitar queimadas no entorno e nos abrigos) e ações de divulgação e educação patrimonial.
\end{abstract}

Palavras-chave: Pinturas rupestres, abrigos sob rocha, patrimônio arqueológico, conservação da natureza, Formação Furnas, região dos Campos Gerais.

\footnotetext{
Abstract

This research presents a study about the archaeological sites of the Pitangui river valley, in the municipality of Ponta Grossa, State of Paraná. As results, it presents management measures for these archaeological sites, in order to harmonize the different interests of use with the conservation of this heritage. The shelters are conceptualized in this study as caves, with their use and protection
} 
regimes also linked to Brazilian speleological legislation. In the researched area, four shelters were characterized that constitute particular archaeological sites, named Abrigo Pitangui I, Abrigo Pitangui II, Abrigo Vale dos Escoteiros and Abrigo Usina São Jorge. In these sites, there are rock paintings associated with the archaeological traditions Planalto and Geométrica. In these caves, negative impacts were identified, mainly due to the vulnerability of these places due to: a) fires; b) graffiti on rock paintings; c) purposeful breaking of panels with rock paintings; d) intense tourist visitation; e) erosive processes caused by motocross trails and; f) mischaracterization of native vegetation around the shelters. It is concluded that the primary management measures of these archaeological sites involve the creation or expansion of protected areas (mainly protected areas of integral protection or listed cultural heritage), constant inspection, maintenance (mostly to avoid a fire in the surroundings and the shelters) and actions of patrimonial disclosure and education.

Keywords: Rock paintings, rock shelters, archaeological heritage, nature conservation, Furnas Formation, Campos Gerais region.

\section{INTRODUÇÃO}

A região dos Campos Gerais do Paraná foi definida por Maack (1948), com base em sua vegetação, formada por campos secos e úmidos. Esses campos são considerados como vegetação relíquia, uma vez que são resquícios que indicam momentos de climas mais secos durante o Quaternário (últimos 1,8 milhões de anos) (MELO; MORO; GUIMARÃES, 2007). Com o aumento de temperatura e umidade durante os últimos milhares de anos a Floresta Ombrofila Mista (fitofisionomia pertencente ao Bioma Mata Atlântica) tem avançado sobre os campos, que ainda se faz presente devido à influência da Escarpa Devoniana, como barreira geomorfológica, e das rochas areníticas da Formação Furnas, que resultam em solos pobres e rasos e desfavorecem o desenvolvimento de vegetação arbórea (MELO; MORO; GUIMARÃES, 2007).

Os Campos Gerais são conhecidos por suas belezas naturais e descrito e retratado por incontáveis naturalistas, viajantes, cientistas e artistas desde o início do século XIX. Abriga inúmeros pontos turísticos, que incluem cachoeiras, corredeiras, balneários, rios, lajeados, paredões rochosos, cavernas e paisagens destinadas para a contemplação da natureza. Por possuir importantes pontos de interesse científico/educacional a região também é utilizada para atividades de ensino, pesquisa e extensão por pesquisadores, professores e alunos oriundos de várias áreas do Brasil. Além disso, há vasta opção de locais para a prática de atividades de aventura, como escalada, trekking (com trilhas e travessias), mountain bike, rapel, motocross trial, exploração de cavernas, etc.

Mesmo sendo considerada uma das regiões que mais atrai turistas no Brasil, a informalidade das atividades e empreendimentos turísticos, ainda muito tímidos, não possibilita identificar um número de visitantes total, ao menos mais próximo da realidade. Entretanto, algumas estimativas podem ser realizadas para as duas principais unidades de conservação de Ponta Grossa, o Parque Nacional dos Campos Gerais e o Parque Estadual de Vila Velha. De acordo com dados do 
ICMBio (2017) e Paraná Projetos (2015) estas duas unidades somam juntas uma média de 140 mil visitantes por ano, evidenciando a alta demanda turística regional. Cabe pontuar que os dados estão desatualizados, sobretudo em relação ao Parque Nacional dos Campos Gerais, pois três de seus principais atrativos turísticos passaram por reformas e melhorias, o que resultou no aumento do número de visitantes e aprimoramento no controle do número de turistas nos últimos anos.

Contudo, este elevado número de visitantes, atrelado com a ainda persistente falta de infraestrutura em muitos dos pontos turísticos, tem resultado em problemas na gestão e conservação de locais com elevada fragilidade ambiental, muitos dos quais com presença de elementos de alto valor científico, histórico ou cultural. Nestas situações se enquadram as cavidades naturais subterrâneas e os sítios arqueológicos.

As áreas de campo apresentam inúmeros afloramentos das rochas da Formação Furnas, que por suas características litofaciológicas, formam inúmeros abrigos e grutas. Estas cavidades foram utilizadas por povos primitivos, paleoindígenas caçadores e coletores, que deixaram registrado seus hábitos, atividades e percepções através de pinturas em paredes e tetos de abrigos naturais sob rocha.

Assim, o uso turístico de abrigos e grutas que possuem patrimônio arqueológico pode constituir um problema frente à conservação destes bens histórico/culturais. Neste sentido, o presente artigo apresenta um estudo realizado nos sítios arqueológicos do vale do rio Pitangui, no município de Ponta Grossa, a fim de caracterizar os impactos negativos ocasionados pelos diferentes usos no local, sobretudo as atividades turísticas. O objetivo desta pesquisa é apresentar medidas de gestão destes sítios arqueológicos, a fim de harmonizar os diferentes interesses de uso com a conservação deste patrimônio.

\section{2. ÁREA DE ESTUDO}

A área de estudo situa-se no médio curso do rio Pitangui, afluente da margem direita do Rio Tibagi. Os abrigos com pinturas rupestres estão localizados a jusante da represa de Alagados, totalmente dentro da Área de Tombamento e da Área de Proteção Ambiental (APA) da Escarpa Devoniana. Parte do recorte espacial deste trabalho está dentro da zona de amortecimento do Parque Nacional dos Campos Gerais, incluindo o Abrigo Vale dos Escoteiros, e apenas o Abrigo Pitangui II está fora da Zona de Proteção 3 - ZP3, área de uso mais restritivo da referida APA (figura 1). 


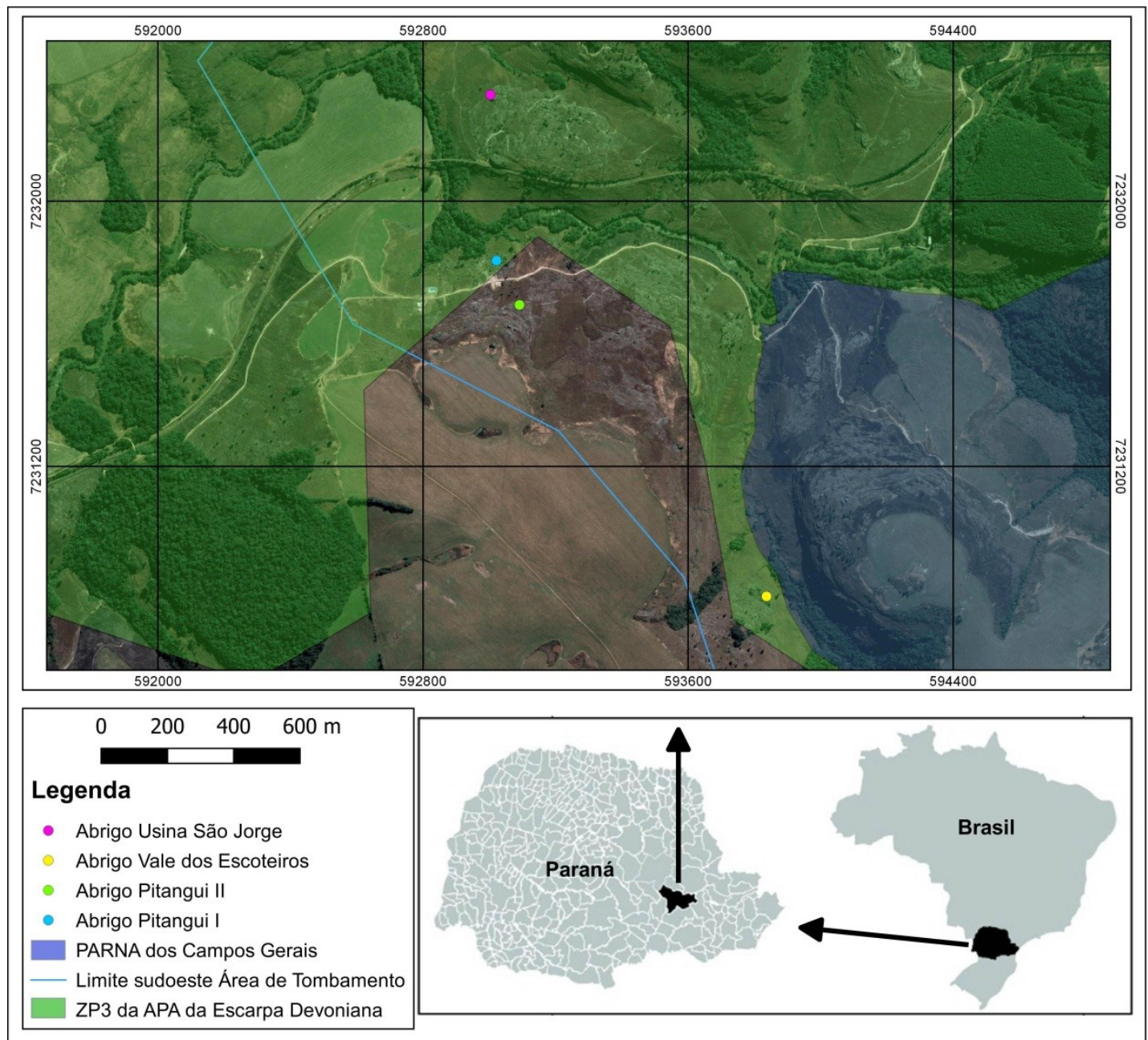

Figura 1 - Mapa de localização da área da pesquisa.

A geologia do local é composta por rochas pertencentes à Formação Furnas (Siluriano/Devoniano da Bacia do Paraná), constituída principalmente por arenitos quartzosos intercalados com arenitos conglomeráticos, com presença de camadas centimétricas a decimétricas de conglomerados, siltitos e argilitos. Conforme Pontes (2020), a combinação de características litofaciológicas desta unidade geológica, como descontinuidades (tectônicas e sedimentares), composição e textura, a par de acentuado processo de intemperismo químico atuante sobre estes litotipos, possibilita a existência de mais de uma centena de cavidades naturais subterrâneas, locais propícios para a ocorrência de registros rupestres, principalmente nos pequenos abrigos e grutas.

O relevo local é formado por canyons e vales bem entalhados, a exemplo do Vale dos Escoteiros. Apresenta encostas íngremes, com desníveis superiores a 140 metros e porções com forte inclinação (maior que 100\%), em alguns casos formando paredões totalmente verticalizados. Estruturas relacionadas com o Arco de Ponta Grossa (de direção NW-SE) exercem marcante controle no relevo e drenagem regional, sendo esta condição facilmente observável na área de estudo. Os solos são arenosos e rasos, compostos, sobretudo de Organossolos e Neossolos Litólicos, além de várias porções com afloramentos rochosos. 
A área de estudo é predominante constituída por campos nativos secos e úmidos (brejosos), campos sujos, floresta Ombrófila Mista com presença de Araucárias (principalmente em áreas ao entorno de canais fluviais, formando matas ciliares) e afloramentos rochosos. Há forte dispersão de Pinus sp., espécie arbórea exótica e invasora, possivelmente oriundas de três fontes de disseminação localizadas a norte da área da presente pesquisa.

\section{PROCEDIMENTOS METODOLÓGICOS}

A presente pesquisa foi dividida em três etapas de campo e uma etapa laboratorial. Na primeira etapa de campo foi realizado o mapeamento dos quatro abrigos que constituem sítios arqueológicos, com o intuito de fornecer informações sobre a forma vertical e horizontal destes espaços e, principalmente, apontar a localização exata das pinturas rupestres nos abrigos. $\mathrm{O}$ levantamento topográfico teve como base as técnicas de mapeamento de cavidades naturais subterrâneas e baseou-se na graduação proposta pela Union Internationale de Spéléologie (UIS). Os equipamentos utilizados nesta etapa incluiu uma Trena Laser Leica modelo DISTO D810 touch Pack e um smartphone Samsung On7 com aplicativo TopoDroid 5.0a (Cave mapping) para recepção e tratamento dos dados.

Na segunda parte da etapa de campo foi realizada a caracterização das pinturas rupestres de cada sítio, o que envolveu a descrição das características das gravuras e enquadramento de tradições. O registro digital fotográfico foi utilizado como base para a descrição das representações, seguindo as considerações de Pereira, Rubio e Barbosa (2013). Para estes autores, a documentação digital permite identificar partes das gravuras rupestres que em muitos casos não são observadas apenas com a inspeção ocular. Para ampliar os detalhas das artes rupestre as fotografias obtidas com máquina fotográfica foram tratadas com filtros IDStretch, uma extensão utilizada a partir do programa ImagemJ, com a utilização de técnicas de realce que permitem observar detalhes e até mesmo figuras inteiras que não são vistas nem mesmo com a utilização de câmera fotográfica (HARMAN, 2019).

A terceira parte do campo incluiu análise dos impactos ambientais negativos diretos e indiretos presentes nos abrigos e entorno imediato. Nesta etapa foi elaborado um quadro contendo a matriz de impacto ambiental na área pesquisada, para identificação dos fatores de risco ao patrimônio arqueológico e propostas de gestão dos sítios, incluindo objetivos e ações.

A etapa laboratorial incluiu a revisão de literatura, processamento e análise dos dados coletados em campo, produção dos mapas e aplicação dos filtros nas fotografias das gravuras rupestres e discussão dos resultados obtidos, a fim de apontar as ações para o manejo e proteção dos sítios arqueológicos. 
O estudo apresenta produtos cartográficos e para a geração de mapas temáticos (localização da área de investigação, localização das feições geológicas, área com ocorrência de queimadas, uso e cobertura do solo) foi utilizado ambiente SIG - Sistemas de Informação Geográfica através do programa QGIS Desktop 2.18.0 with GRASS 7.0.5 (disponível gratuitamente para download na internet) e softwares $C A D$ para desenho de mapas espeleológicos, como o programa livre $O C A D P R O$ 8. Os materiais utilizados nesta etapa da pesquisa incluíram Imagens Orbitais Maxar Technologies (2013; 2016; 2017 e 2019): Google Earth Pro; Limite territorial municipal, estadual e do Brasil: Instituto Brasileiro de Geografia e Estatística (IBGE).

\section{RESULTADOS}

\subsection{Caracterização dos abrigos}

Os sítios arqueológicos do vale do rio Pitangui são classificados como cavidades naturais subterrâneas do tipo abrigos desenvolvidos nas rochas da Formação Furnas, constituindo lapas com dimensões laterais maiores (com mais de 20 metros de desenvolvimento linear) do que a projeção horizontal (até 8 metros). Apenas os abrigos Vale dos Escoteiros e Pitangui II apresentam porção espessa entre o teto do abrigo e a superfície do terreno, acima da cavidade (mais de 5 metros). Os demais abrigos possuem baixa espessura, com destaque ao Abrigo Usina São Jorge que possui pouco mais de meio metro de camada de rocha até a superfície.

Todos os abrigos apresentam forte controle de estruturas sedimentares, e o intemperismo atua exatamente nestas descontinuidades entre camadas e nas estratificações plano-paralela, desestabilizando a rocha e possibilitando o abatimento dos estratos. Aos poucos, o deslocamento natural de placas de diferentes tamanhos abre espaço nos paredões e afloramentos, formando lapas de tetos baixo e alto. Características faciológicas das rochas da Formação Furnas também contribuem para a formação destas cavidades subterrâneas, conforme reportado por Pontes (2020), incluindo alteração da textura e cimentação. Além disso, existência de diferentes padrões de faturamento é outro fator que fragiliza estas rochas, favorecendo o desenvolvimento de cavidades de diversos tamanhos.

Estes abrigos sob rocha com pinturas rupestres são predominantemente dispostos para Norte, Nordeste ou Noroeste. De acordo com Oliveira (2014) esta característica pode revelar o interesse dos povos primitivos de beneficiar-se da insolação máxima. Esta condição, segundo a autora, favorece a salubridade das pinturas. Caso contrário ocorre aos abrigos voltados para a face sul, pois o aumento da umidade eleva o desenvolvimento da biota e consequentemente do intemperismo químico, o que causa a degradação das pinturas. 
$\mathrm{Na}$ área de estudo foram caracterizados quatro abrigos que constituem sítios arqueológicos distintos. O Abrigo Pitangui I situa-se a aproximadamente 100 metros do rio de mesmo nome, apresentando dimensões de 5 metros de altura no ponto mais alto, 13 metros de extensão lateral e 4 metros de projeção horizontal (figura 2). Localizado a aproximadamente 250 metros do rio Pitangui, o Abrigo Pitangui II possui dimensões de 3,8 metros de altura no ponto mais alto, 18 metros de extensão lateral e 8 metros de projeção horizontal (figura 3). O Abrigo Vale dos Escoteiros dista cerca de 850 metros do Rio Pitangui, apresenta dimensões de 3,8 metros de altura no ponto mais alto, 24 metros de extensão lateral e 7 metros de projeção horizontal (figura 4). O único sítio arqueológico localizado na margem direita do Rio Pitangui, a aproximadamente 200 metros do curso hídrico, o Abrigo Usina São Jorge possui 3 metros de altura no ponto mais alto, 26 metros de extensão lateral e 5 metros de projeção horizontal (figura 5).

Todos os abrigos apresentam vegetação rupestre, arbustiva e nas paredes e teto ocorrem epífitas, musgos e liquens. Em alguns casos, principalmente liquens e musgos ocasionam a degradação das rochas e, mesmo que de maneira natural, impactam negativamente as pinturas rupestres, devido à aceleração de decomposição por desplacamento do arenito e recobrimento parcial ou completo das artes rupestres.

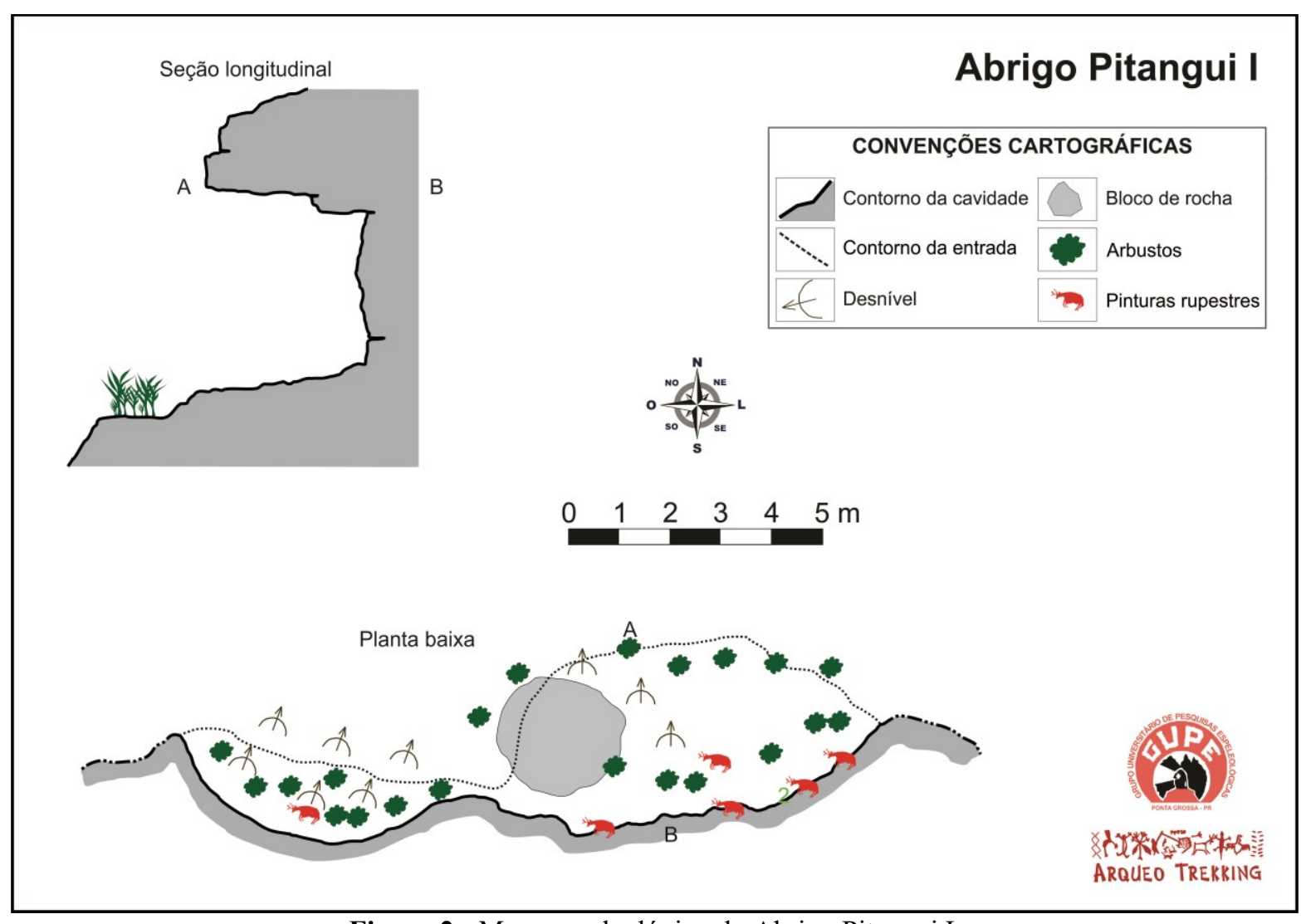

Figura 2 - Mapa espeleológico do Abrigo Pitangui I. 


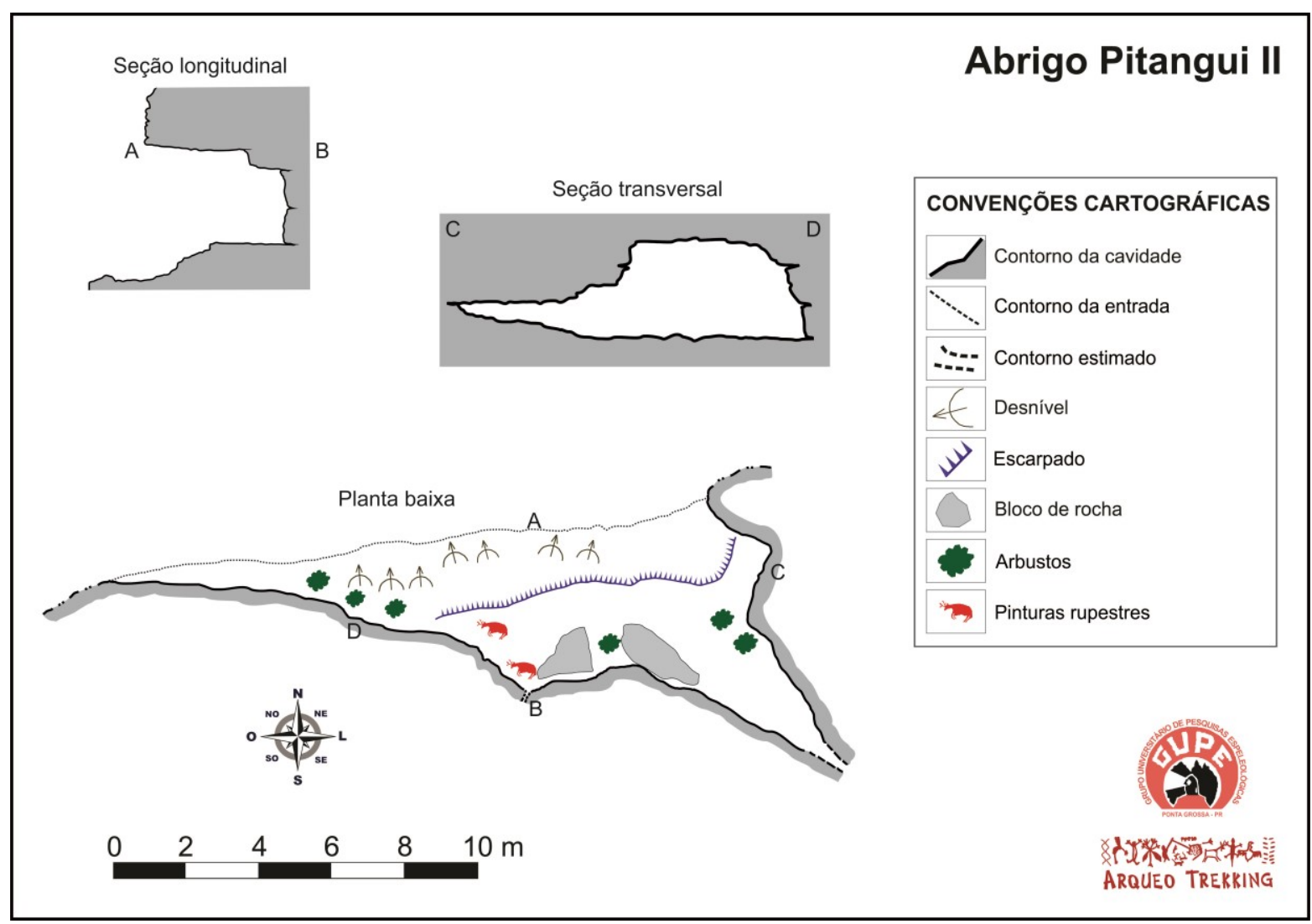

Figura 3 - Mapa espeleológico do Abrigo Pitangui II.

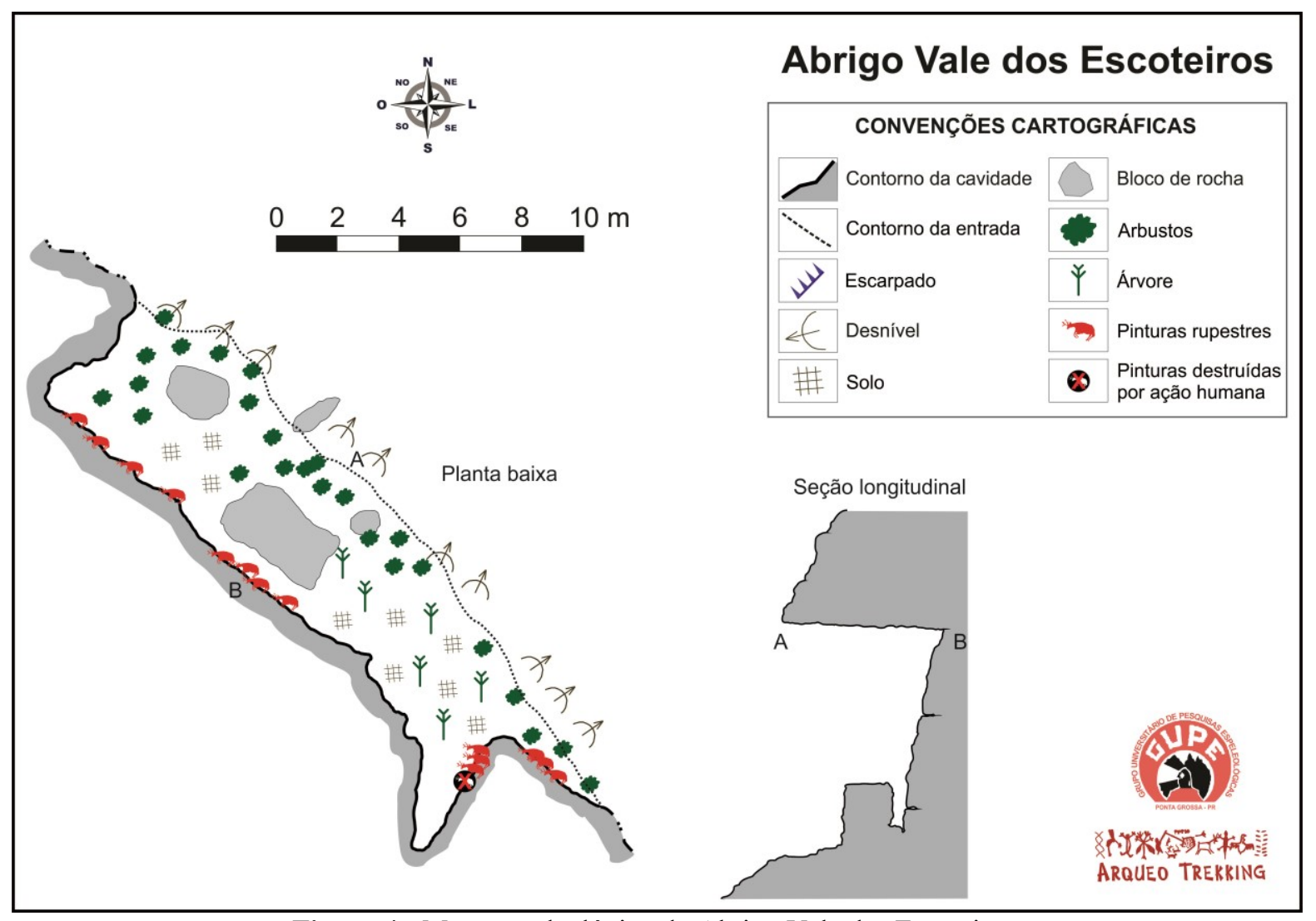

Figura 4 - Mapa espeleológico do Abrigo Vale dos Escoteiros. 


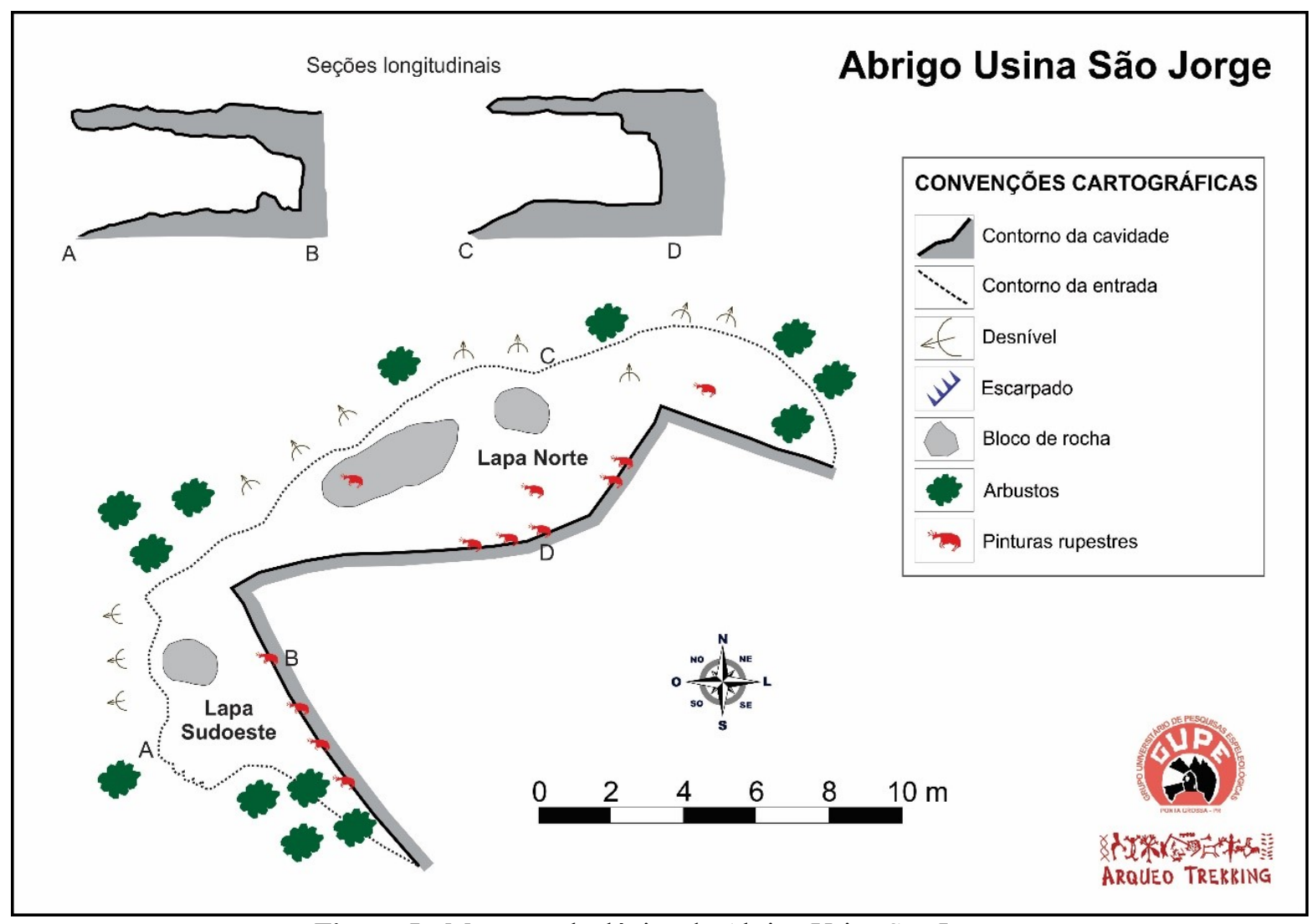

Figura 5 - Mapa espeleológico do Abrigo Usina São Jorge.

\subsection{Descrição das pinturas rupestres}

A maior parte dos sítios arqueológicos da região é constituída por abrigos sob rocha, lapas de pedra, e/ou cavernas areníticas com pinturas rupestres. Esses sítios são filiados às tradições arqueológicas Planalto e Geométrica, com base nos estudos de Blasi (1970), Blasi (1972), Blasi et al. (1991), Parellada (1993) apud. Silva (1999). A Tradição Planalto é caracterizada principalmente pela grande presença de representações de animais (cervídeos e emas), e a Tradição Geométrica é representada basicamente por traços, linhas e pontilhados.

\subsubsection{Abrigo Rio Pitangui I}

A totalidade das representações rupestres do Abrigo Rio Pitangui I são monocromáticas de cor avermelhada, atribuídas as Tradições Planalto e Geométrica, em sua maior parte em um painel na parede do abrigo, e algumas ocorrências no teto. A parede do abrigo, pelo fato de estar mais exposta as intempéries e raios solares, passou por processos de desplacamento de algumas camadas da rocha, danificando boa parte das pinturas deste painel. Em sua grande maioria são representações zoomorfas (cervídeos e aves), uma possível representação antropomorfa (silhueta de uma figura humana), e uma única representação geométrica, traços alinhados em duas fileiras (figura 6). A pintura mais representativa deste abrigo está no teto da cavidade, se trata de uma representação de 
um cervídeo galhado, chapado e com as patas dianteiras curvadas, aparentando movimento, segundo a tabela de classificação de cervídeos de Prous (1992) (figura 7).

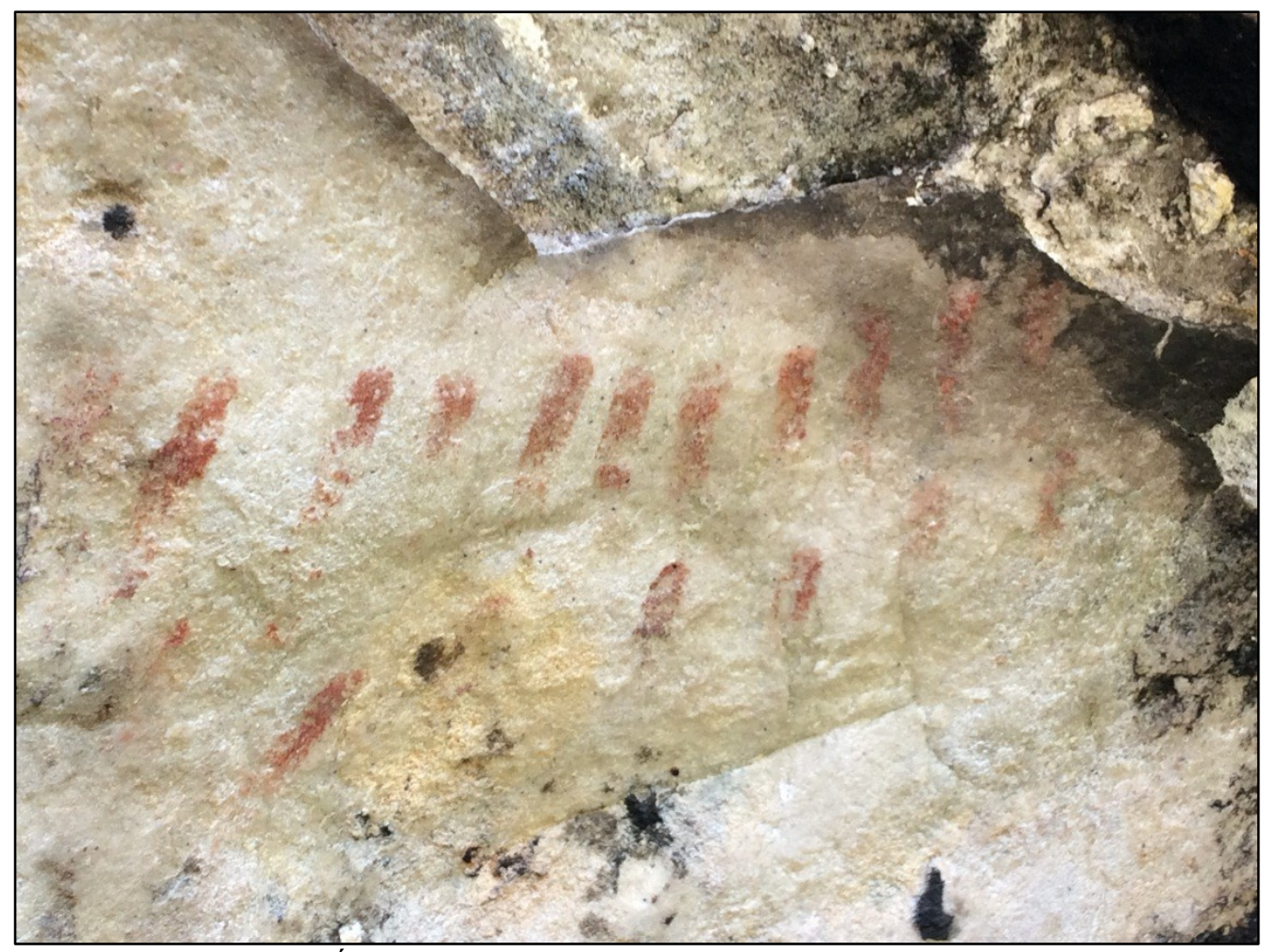

Figura 6 - Única representação geométrica do Abrigo Rio Pitangui I.

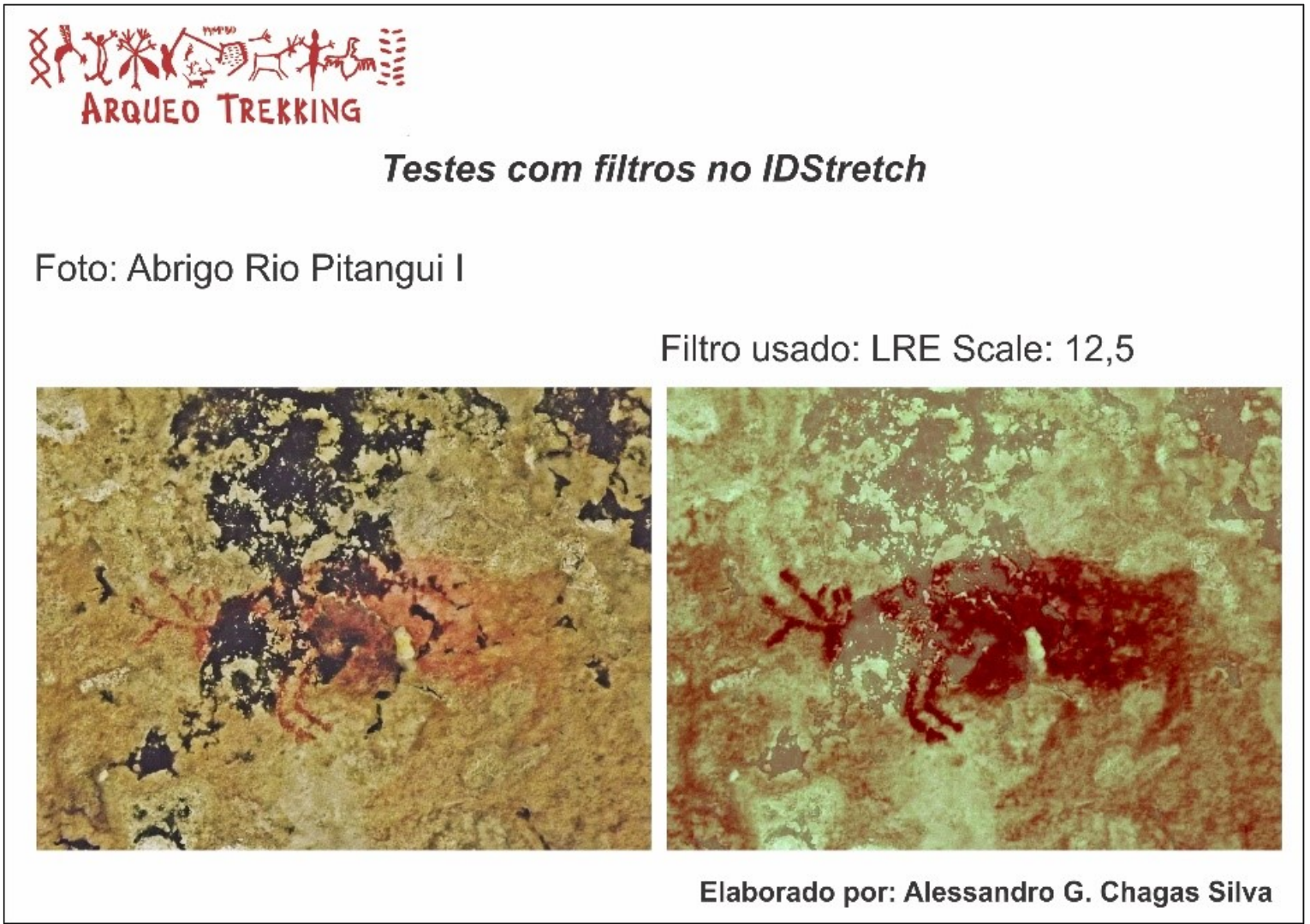

Figura 7 - Representação no teto do Abrigo Rio Pitangui I, com aplicação de filtro via IDStretch, com cervídeo galhado chapado com patas curvas dando impressão de movimento. 


\subsubsection{Abrigo Rio Pitangui II}

É o sítio arqueológico com menos representações na área de abrangência da pesquisa, possui apenas duas pinturas, uma de difícil interpretação em uma cornija no teto bem próximo a parede (figura 8), e outra, possivelmente um cervídeo listrado, também no teto no centro do abrigo. Os abrigos Rio Pitangui I e II estão bem próximos da piscina e lanchonete da Fazenda Rio Pitangui, havendo assim a necessidade de um plano de manejo com orientações aos proprietários e visitantes e turistas que frequentam o local.

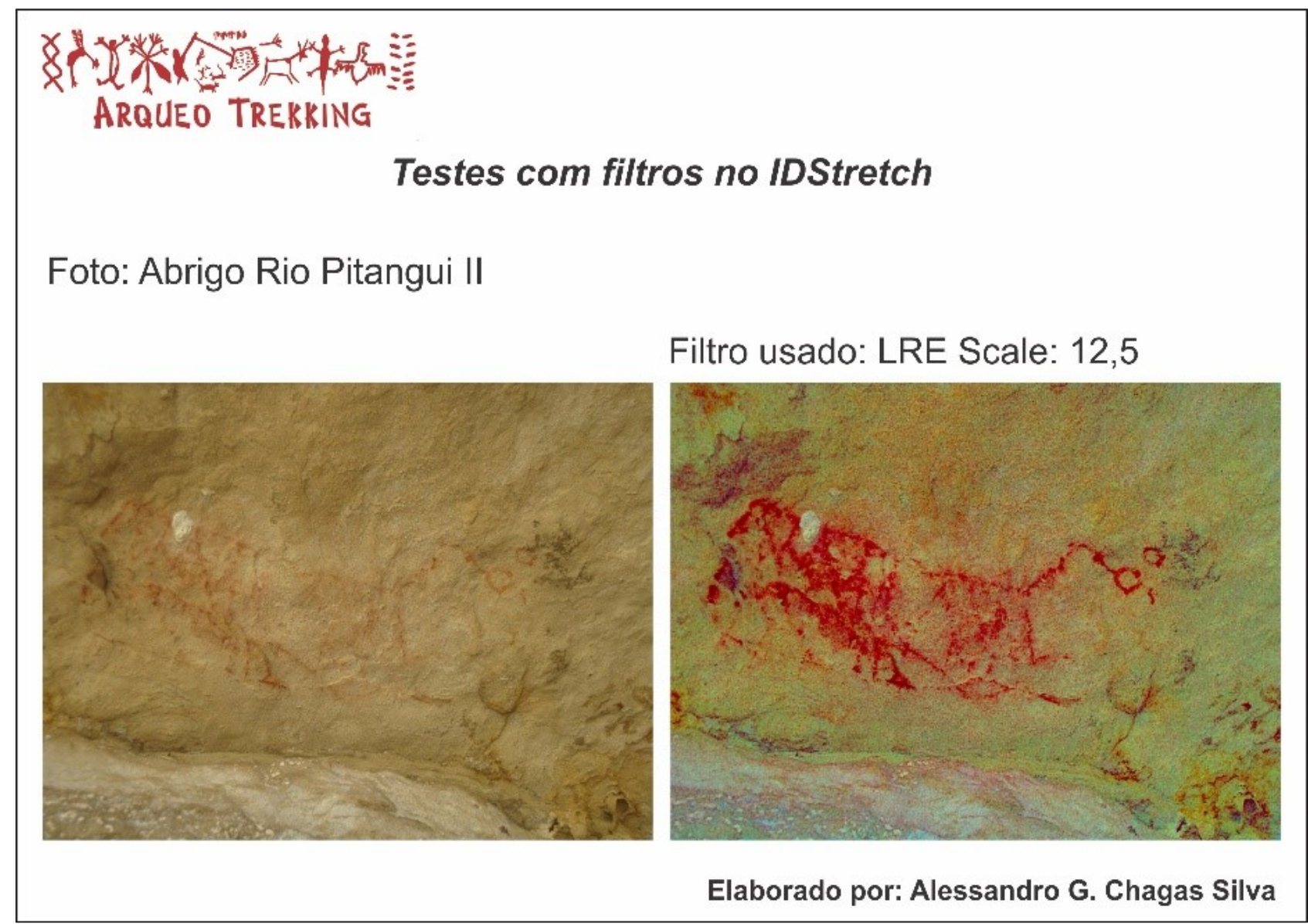

Figura 8 - Representação geométrica de difícil interpretação.

\subsubsection{Abrigo Usina São Jorge}

Considerado como um dos sítios arqueológicos mais representativos do município de Ponta Grossa, pesquisado inicialmente no final da década de noventa, uma caracterização do abrigo e classificação das pinturas mais representativas é apresentada no trabalho "Pinturas Rupestres do Sítio Arqueológico Abrigo Usina São Jorge, Ponta Grossa, Paraná” (SILVA, 1999).

Ao longo de todo esse tempo o abrigo passou por algumas depredações antrópicas, situação divulgada em jornal de circulação nacional, em julho de 2015. Após esta vinculação na mídia, uma visita técnica ao referido sítio foi realizada pelo Instituto do Patrimônio Histórico e 
Artístico Nacional (IPHAN) e Coordenação de Patrimônio Cultural da Secretaria do Estado de Cultura do Paraná. Na ocasião foi elaborado um laudo técnico inscrito sob o número 161/2015 junto ao IPHAN/PR, com o objetivo de caracterizar os elementos arqueológicos do sítio e propor recomendações frente aos problemas com a conservação do local (IPHAN, 2015).

Recentemente com novos levantamentos fotográficos e com o auxílio do software IDStretch foram descobertas novas representações no teto da lapa norte (figura 9) e também algumas representações na parede da lapa sudoeste do abrigo (figura 10). As Pinturas Rupestres do Abrigo Usina São Jorge são de suma importância arqueológica e patrimonial, pois em um único sítio temos diversas representações de cervídeos, aves, traços geométricos, sobreposição de pinturas e a famosa "cena de cervídeos" tendo a incomum ocorrência de um cervídeo na cor amarela.

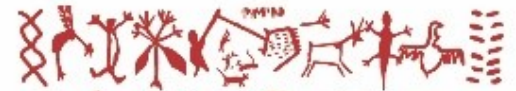 ARQUEO TRERRING
}

Testes com filtros no IDStretch

\author{
Foto: Abrigo Usina São Jorge - Lapa Norte
}

\section{Filtro usado: YRD Scale: 15}
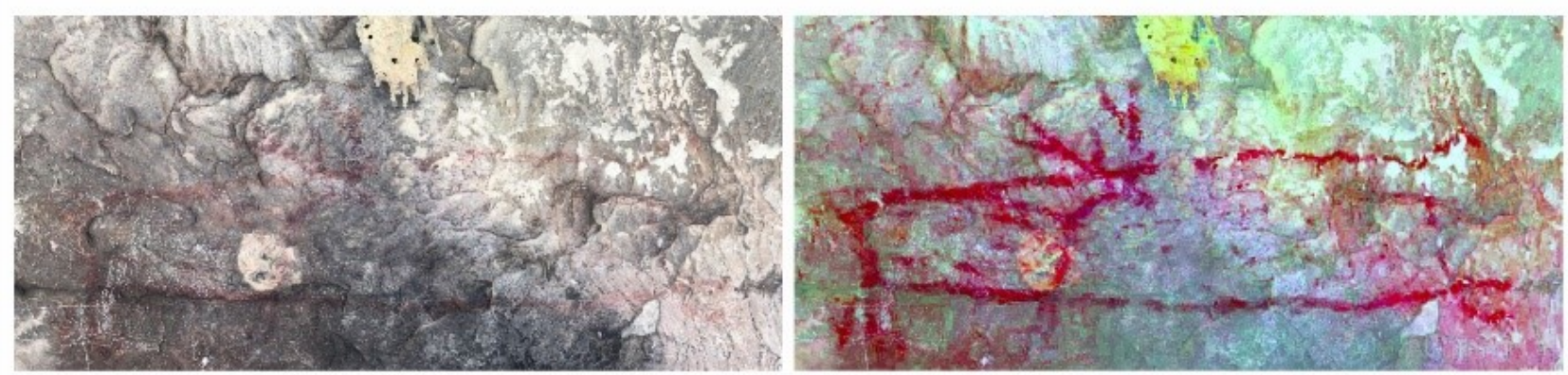

Elaborado por: Alessandro G. Chagas Silva

Figura 9 - Novas descobertas, representação de sobreposição de pinturas "cervídeos" no teto da lapa norte do Abrigo Usina São Jorge. 


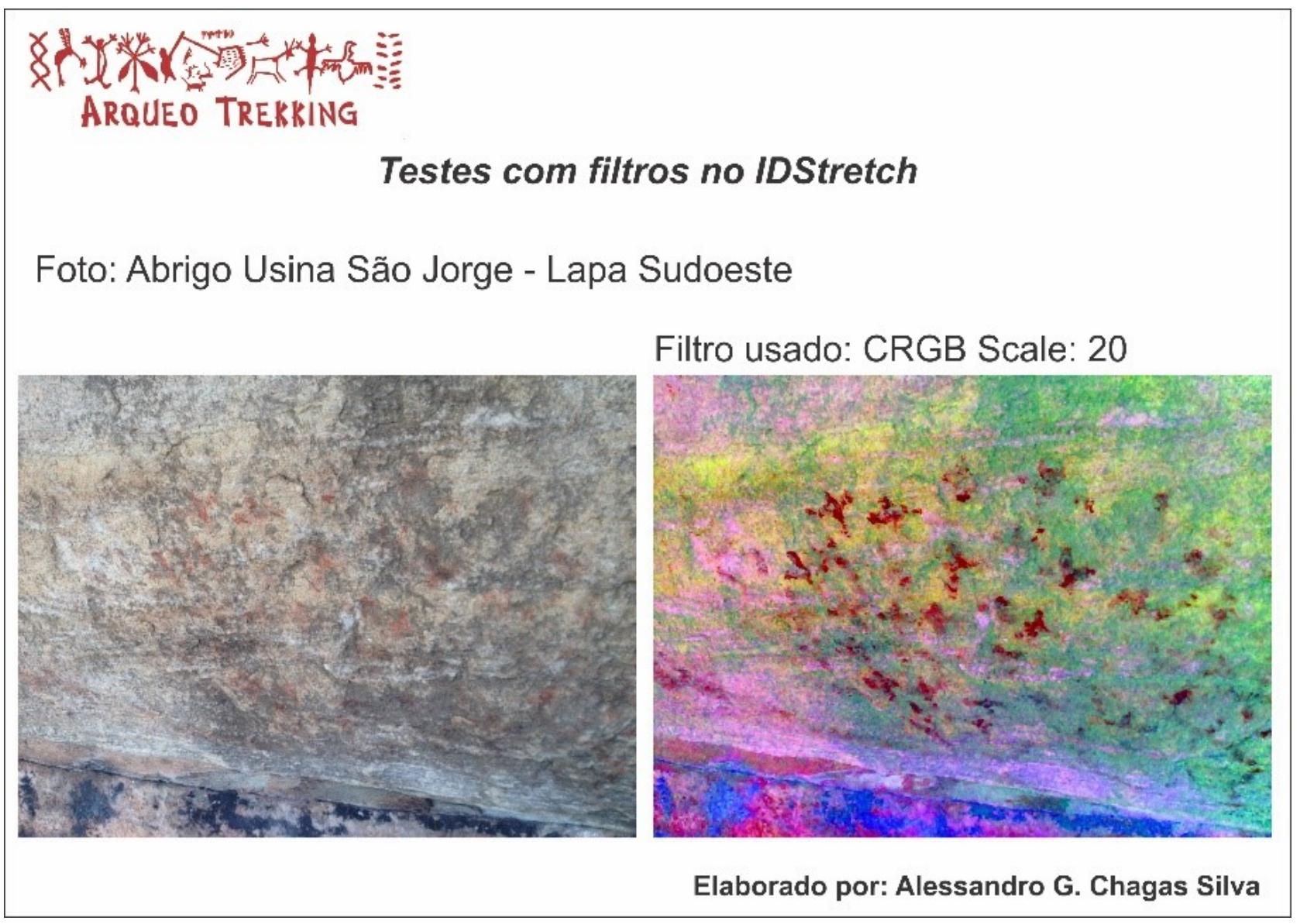

Figura 10 - Representação rupestre da lapa sudoeste do Abrigo Usina São Jorge, semelhante a uma revoada de pássaros.

\subsubsection{Abrigo Vale dos Escoteiros}

É o sítio que se encontra mais distante do Rio Pitangui, cerca de 850 metros, formado por um grande abrigo sob rocha onde todas as suas representações encontram-se na parede da cavidade. Destaca-se a ocorrência de um conjunto de pinturas que inclui traços e pontilhados elaborados em porções altas da parede, local de difícil acesso, provavelmente produzidas com o uso de andaimes para superar o obstáculo imposto pela altura (figura 11). Todas as representações são atribuídas a Tradição Geométrica e a figura mais representativa é uma pintura bicromática de um círculo raiado, onde o centro apresenta cor amarela e seu contorno com traços raiados em vermelho, além de uma porção de cor amarela situada abaixo do conjunto (figura 12). Neste abrigo também ocorrem icnofósseis, traços fósseis de epirelevo côncavo e convexo do icnogênero Palaeophycus sp., na superfície de um bloco de rocha na base do abrigo. 


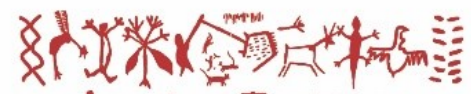 \\ ARQUEO TRERKING \\ Testes com filtros no IDStretch \\ Foto: Abrigo Vale dos Escoteiros \\ Filtro usado: LDS Scale: 20
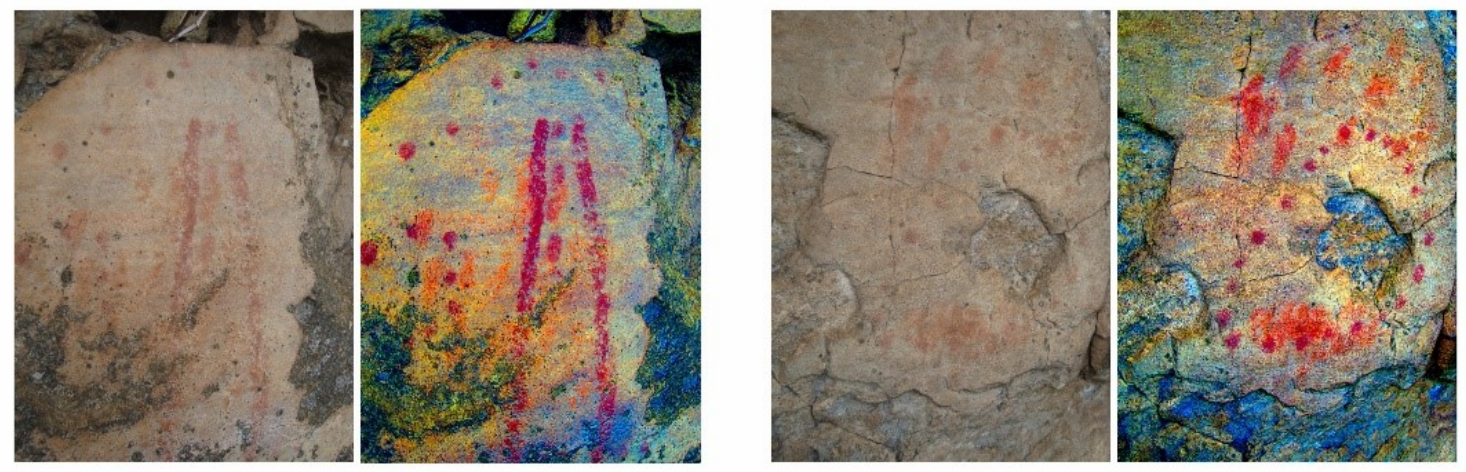 \\ Elaborado por: Alessandro G. Chagas Silva}

Figura 11 - Representações geométricas do Abrigo Vale dos Escoteiros.

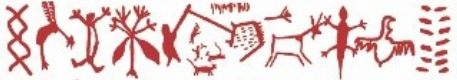

ARQUEO TRERKING

\section{Testes com filtros no IDStretch}

Foto: Abrigo Vale dos Escoteiros

Filtro usado: LRE Scale: 20
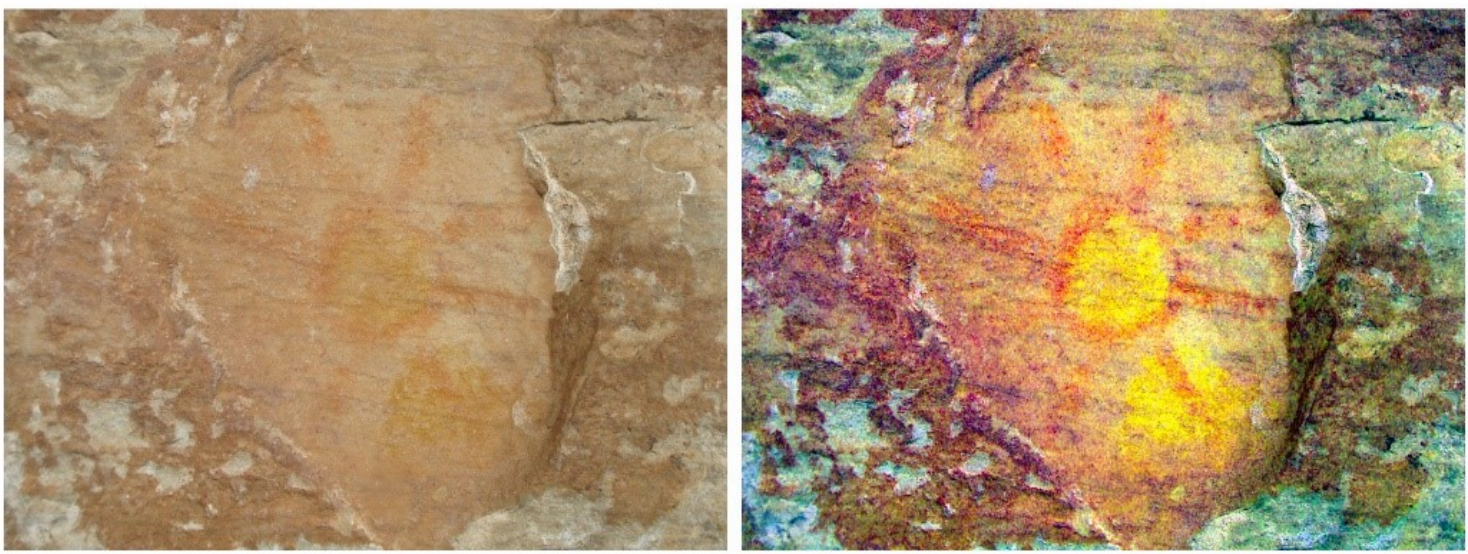

Elaborado por: Alessandro G. Chagas Silva

Figura 12 - Representação bicromática de um círculo raiado, no Abrigo Vale dos Escoteiros. 


\subsection{Uso do solo no entorno dos sítios arqueológicos}

A fim de caracterizar o uso do solo na área de ocorrência dos sítios arqueológicos, são apresentados alguns produtos cartográficos. As figuras 13, 14 e 15 identificam as áreas de plantio e dispersão de Pinus sp., agricultura mecanizada, trilhas de trekking, trilhas de motocross, estradas e outros tipos de usos do solo e equipamentos/infraestrutura. A tabela 1 sintetiza os tipos de uso do solo em cada um dos sítios arqueológicos.

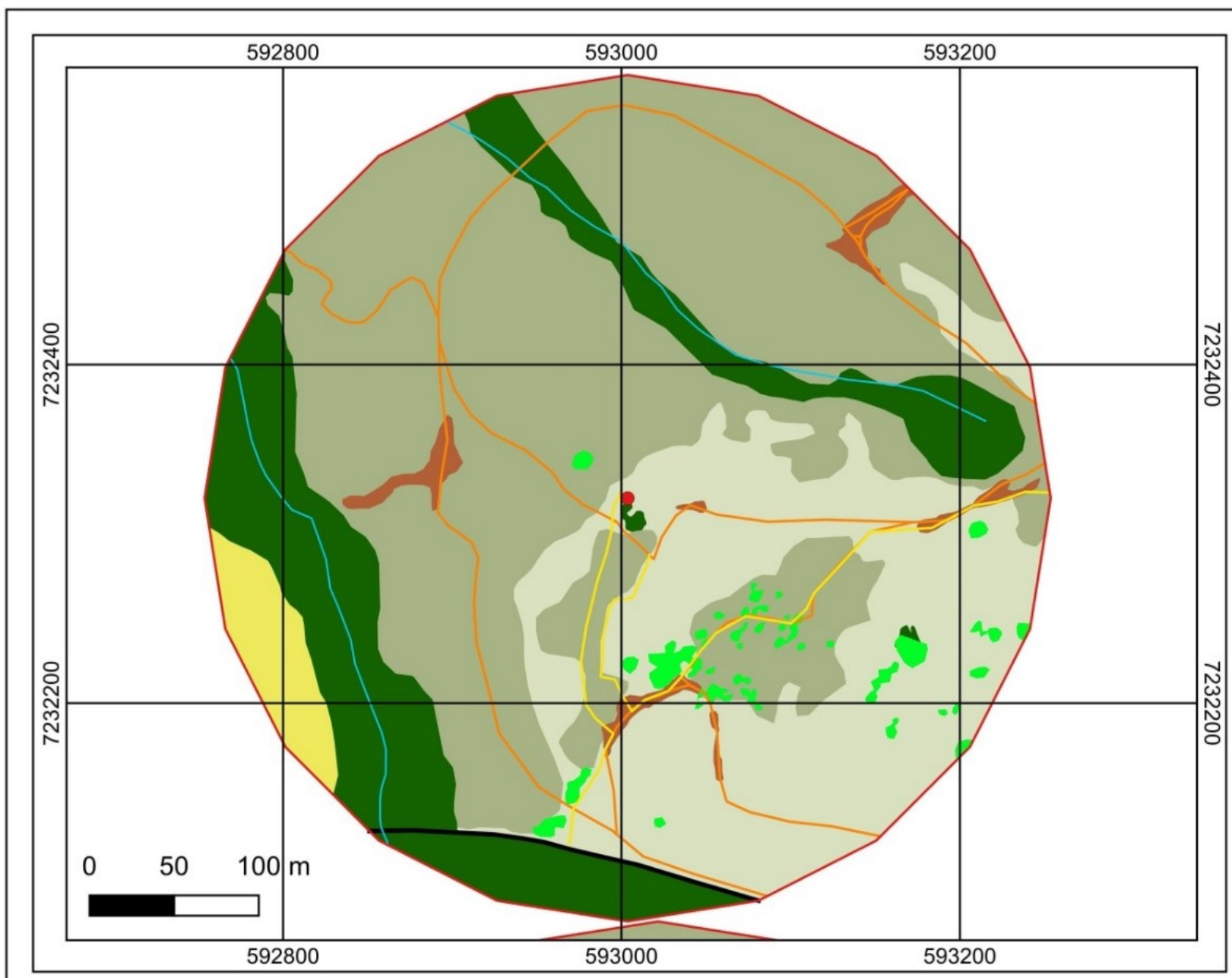

\section{Legenda}

Área de Influência 250m

- Abrigo Usina São Jorge Curso hídrico

Linha de trem
Trilha de trekking

Trilha de motocross

Espécie arbórea exótica

Processo erosivo
Agricultura mecanizada

Floresta

Campo nativo

Campo rochoso

Figura 13 - Mapa de uso e cobertura do solo na área de influência de 250 metros do Abrigo Usina São Jorge. 
Esta análise levou em consideração a Resolução CONAMA nº 347, de 10 de setembro de 2004, que determina que a área de influência das cavidades naturais subterrâneas (que inclui neste conceito os abrigos) é a projeção horizontal da caverna acrescida de um entorno de 250 metros, em forma de poligonal (CONAMA, 2004). Esta mesma resolução aponta que esta metragem só pode ser alterada quando na realização de estudos específicos, devendo assim ser consideradas como áreas protegidas, ou seja, qualquer tipo de uso ou atividade sobre esta zona de influência necessita de processo de licenciamento ambiental espeleológico, seguindo as orientações constantes no Decreto $n^{\circ}$ 6.640/2008 (BRASIL, 2008).

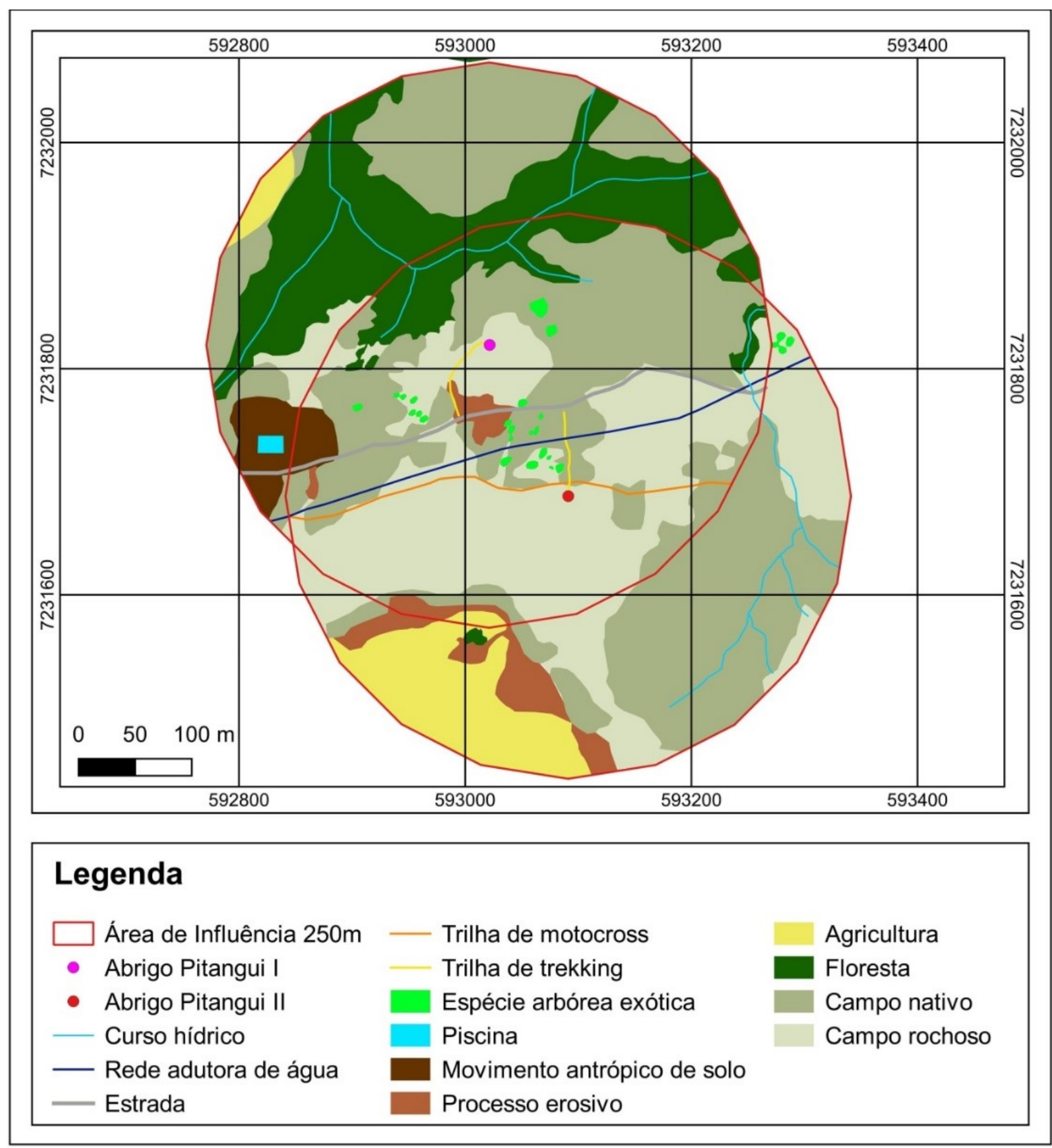

Figura 14 - Mapa de uso e cobertura do solo na área de influência de 250 metros dos abrigos Pitangui I e II. 


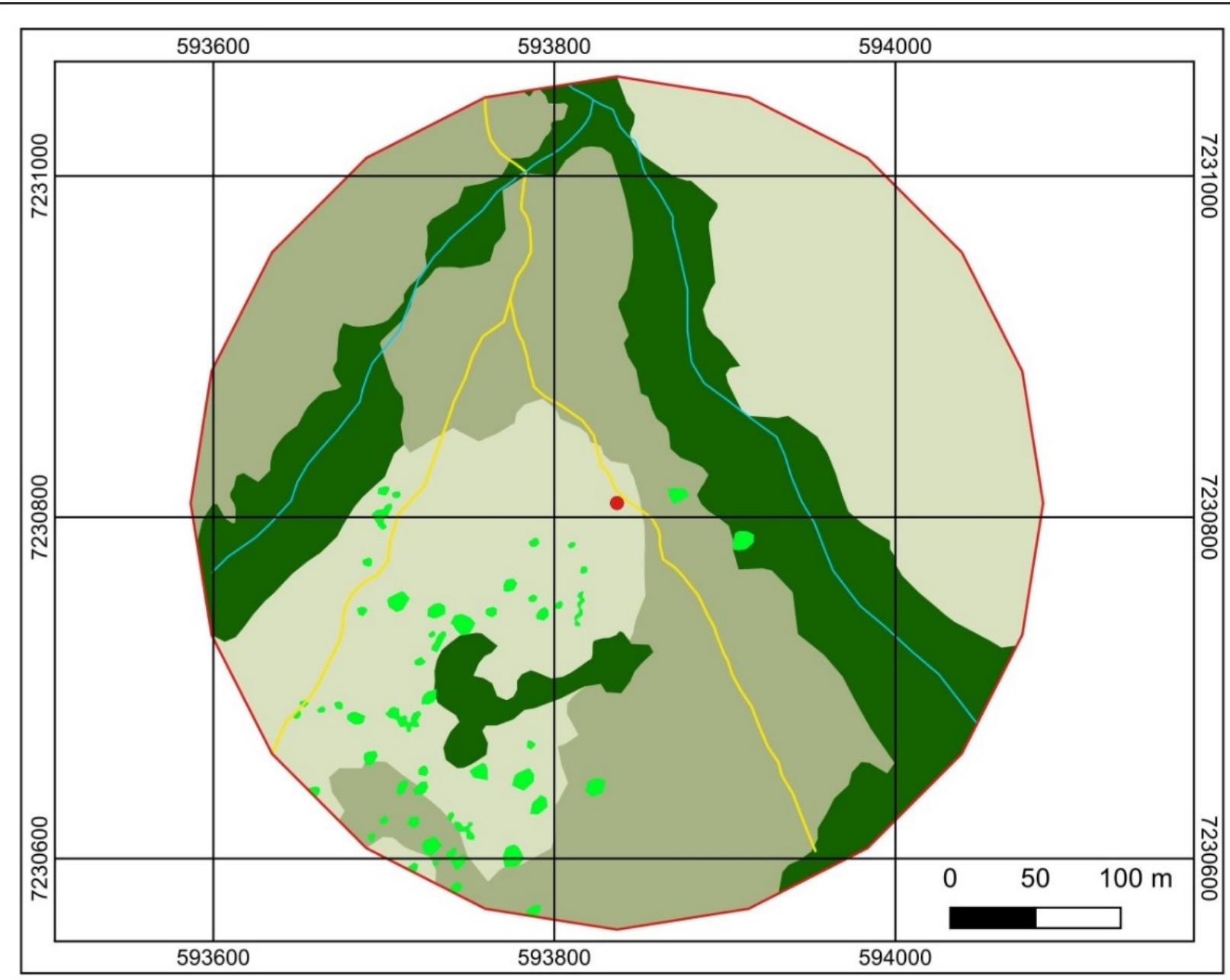

\section{Legenda}

Área de Influência 250m

- Abrigo Vale dos Escoteiros Curso hídrico
Trilha de trekking

Espécie arbórea exótica

Floresta

Figura 15 - Mapa de uso e cobertura do solo na área de influência de 250 metros do Abrigo Vale dos Escoteiros. 
Tabela 1: Detalhamento do uso e cobertura do solo na área de influência de 250 metros dos abrigos que constituem sítios arqueológicos.

\begin{tabular}{|c|c|}
\hline Sítios arqueológicos & Usos e cobertura do solo \\
\hline \multirow[t]{2}{*}{ Abrigo Pitangui I } & $\begin{array}{l}\text { Antrópicos: estrada não pavimentada; rede adutora de abastecimento de água; } \\
\text { agricultura mecanizada; construção civil (piscina); trilha de trekking; trilha de } \\
\text { motocross; dispersão de espécies arbórea exótica (Pinus sp.); processos erosivos; } \\
\text { movimentação antrópica de solo. }\end{array}$ \\
\hline & Naturais: campos nativos; floresta; curso hídrico; afloramentos rochosos. \\
\hline \multirow[t]{3}{*}{ Abrigo Pitangui II } & $\begin{array}{l}\text { Antrópicos: estrada não pavimentada; rede adutora de abastecimento de água; } \\
\text { agricultura mecanizada; trilha de trekking; trilha de motocross; dispersão de } \\
\text { espécies arbórea exótica (Pinus sp.); processos erosivos; movimentação antrópica } \\
\text { de solo. }\end{array}$ \\
\hline & Naturais: campos nativos; floresta; curso hídrico; afloramentos rochosos. \\
\hline & Antrópicos: Trilha de trekking e dispersão de espécies arbórea exótica (Pinus sp.). \\
\hline $\begin{array}{l}\text { Abrigo Vale dos } \\
\text { Escoteiros }\end{array}$ & Naturais: campos nativos; floresta; curso hídrico; afloramentos rochosos. \\
\hline \multirow{2}{*}{$\begin{array}{l}\text { Abrigo Usina São } \\
\text { Jorge }\end{array}$} & $\begin{array}{l}\text { Antrópicos: estrada de ferro; agricultura mecanizada; trilha de trekking; trilhas de } \\
\text { motocross; dispersão de espécies arbórea exótica (Pinus sp.); processos erosivos. }\end{array}$ \\
\hline & Naturais: campos nativos; floresta; curso hídrico; afloramentos rochosos. \\
\hline
\end{tabular}

As figuras 16, 17, 18, 19 e 20 apresentam uma análise da ocorrência de queimadas no vale do Rio Pitangui, exatamente na área dos sítios arqueológicos, em um recorte temporal abrangendo as datas de 06/08/2013 a 22/07/2019.

As queimadas dos anos de 2013 e 2016 atingiram os abrigos. Os registros dos anos de 2017 e 2019 mostram que o fogo não chegou aos sítios, mas se aproximou significativamente. As imagens orbitais disponíveis pela plataforma Google Earth permitem observar que as queimadas se concentram sobre os eixos de circulação de pessoas (linha de trem, trilhas de trekking, trilhas de motocross e estradas), possível evidência de que se tratam de queimadas criminosas (com ou sem intenção).

Apesar de se situarem em áreas de afloramentos rochosos os abrigos são atingidos por fogo devido à existência de campos rochosos, que constituem combustível, mesmo em pouca quantidade, suficiente para as chamas se alastrarem. Principalmente nestes casos, pequenos cursos hídricos desempenham papel fundamental na retenção das queimadas, pois servem como barreiras naturais que impedem o avanço do fogo. Mas, como apontado por Pontes et al. (2018), construção de drenos em nascentes, campos úmidos e pequenos cursos hídricos são práticas comuns na região dos Campos Gerais, ação que pode potencializar as queimadas. 


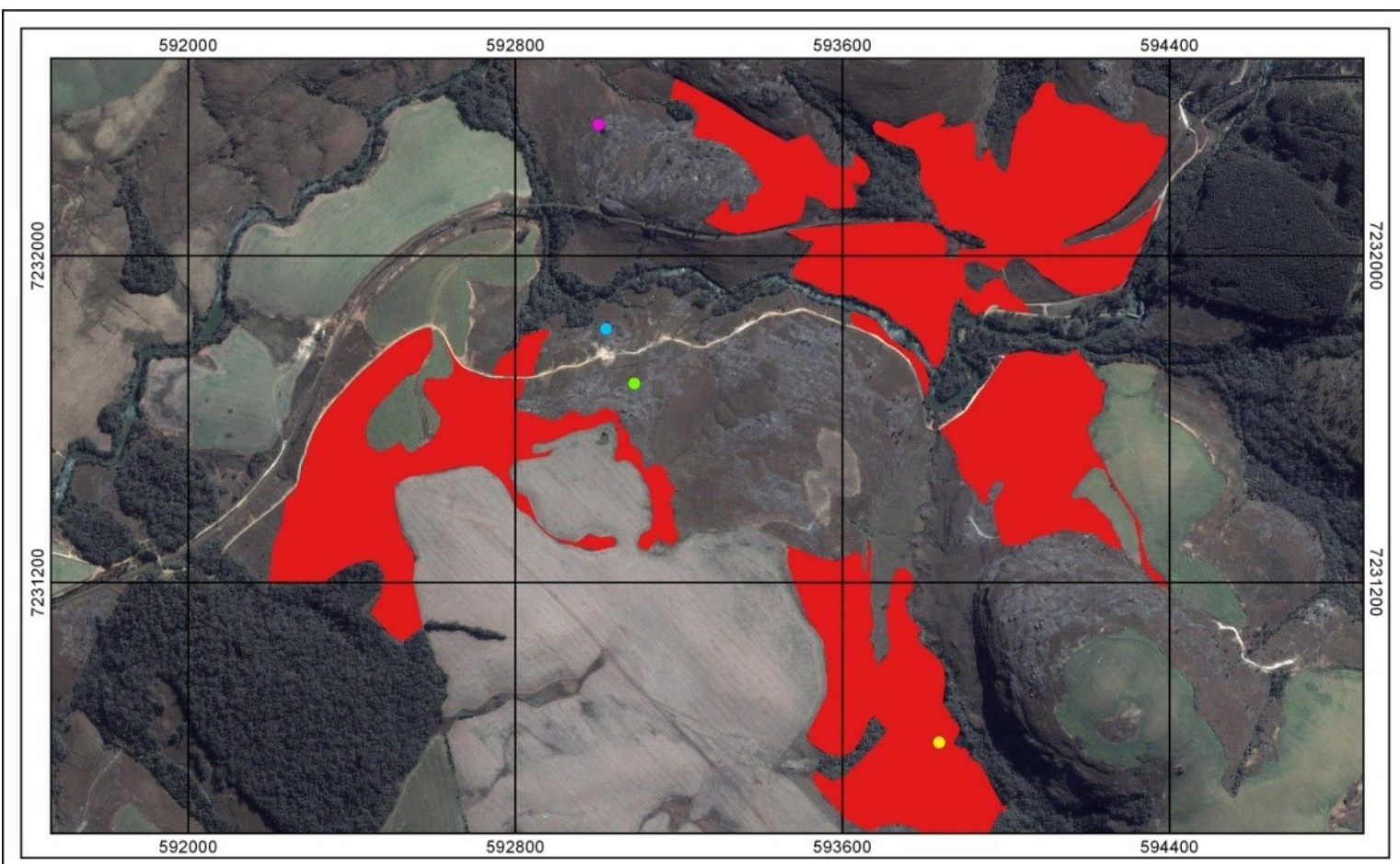

\section{Legenda}

- Abrigo Usina São Jorge

- Abrigo Pitangui I

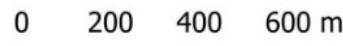

- Abrigo Vale dos Escoteiros

Áreas afetadas por queimadas em 2013

- Abrigo Pitangui II

Figura 16 - Mapa da ocorrência de queimadas no ano de 2013.

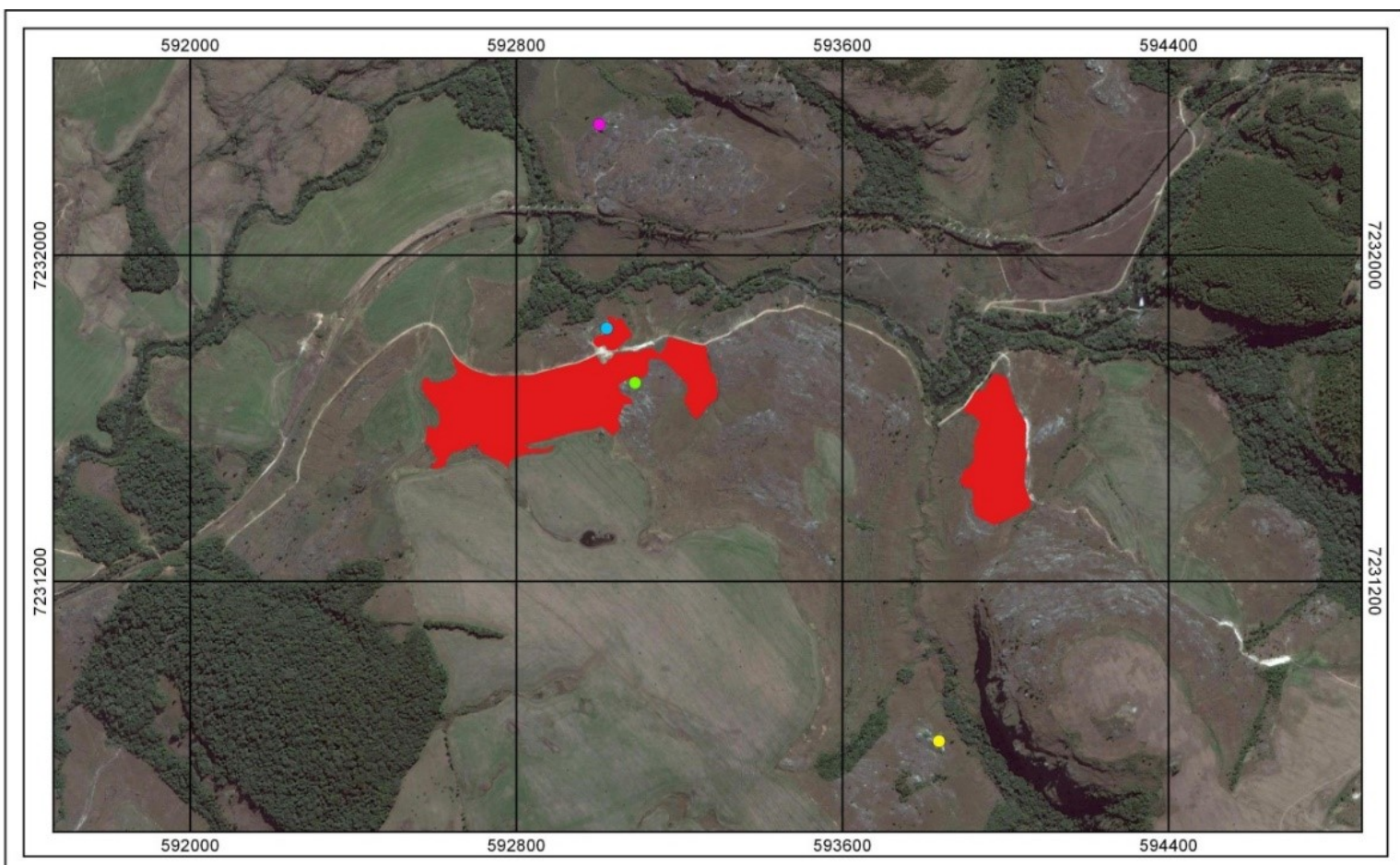

\section{Legenda}

- Abrigo Usina São Jorge

- Abrigo Pitangui

$0 \quad 200 \quad 400 \quad 600$ m

Abrigo Vale dos Escoteiros

Áreas afetadas por queimadas em 06/2016

- Abrigo Pitangui II

Figura 17 - Mapa da ocorrência de queimadas em junho do ano de 2016. 


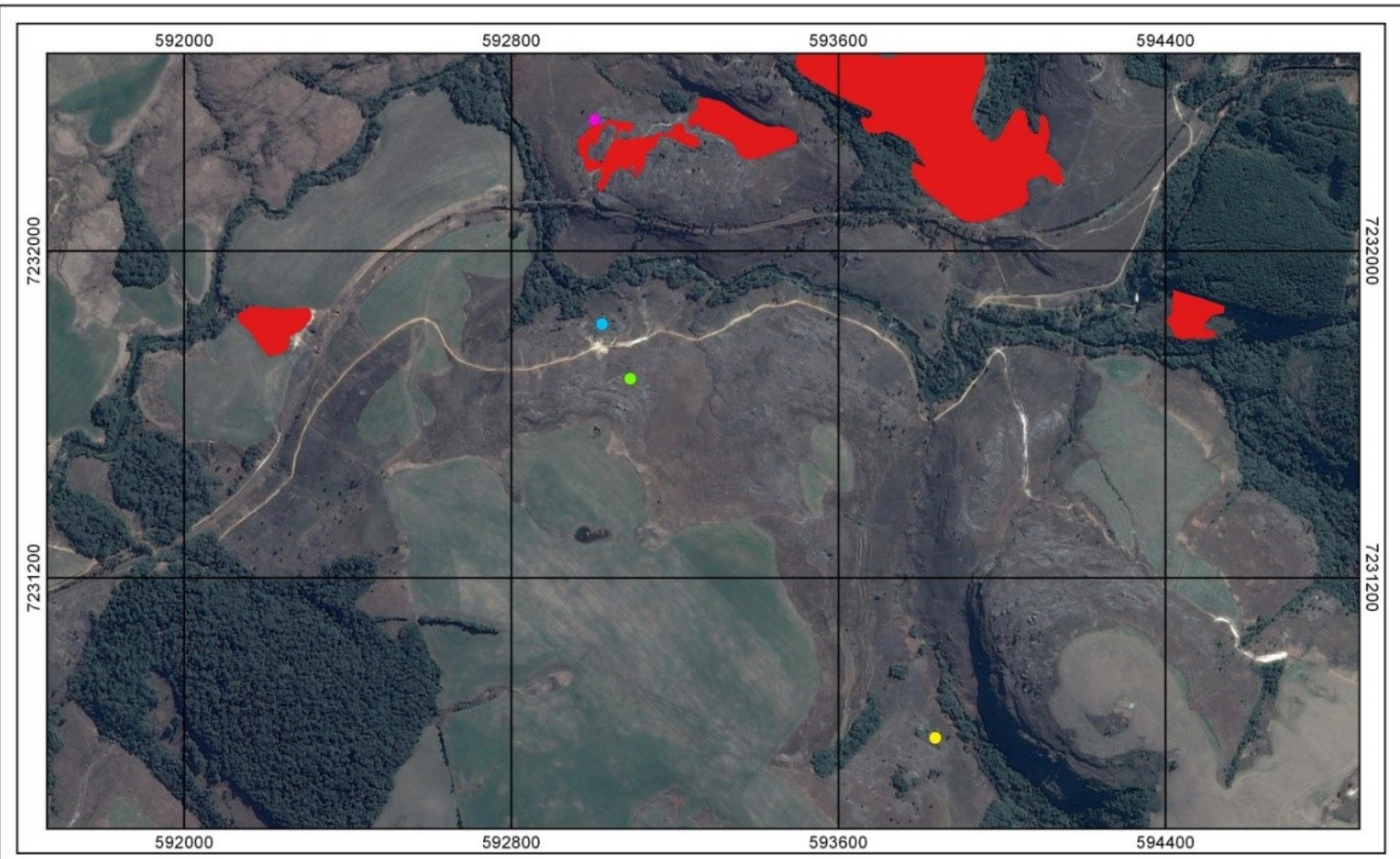

\section{Legenda}

- Abrigo Usina São Jorge

- Abrigo Pitangui I

$0 \quad 200 \quad 400 \quad 600 \mathrm{~m}$

- Abrigo Vale dos Escoteiros

- Abrigo Pitangui II

Figura 18 - Mapa da ocorrência de queimadas em julho do ano de 2016.

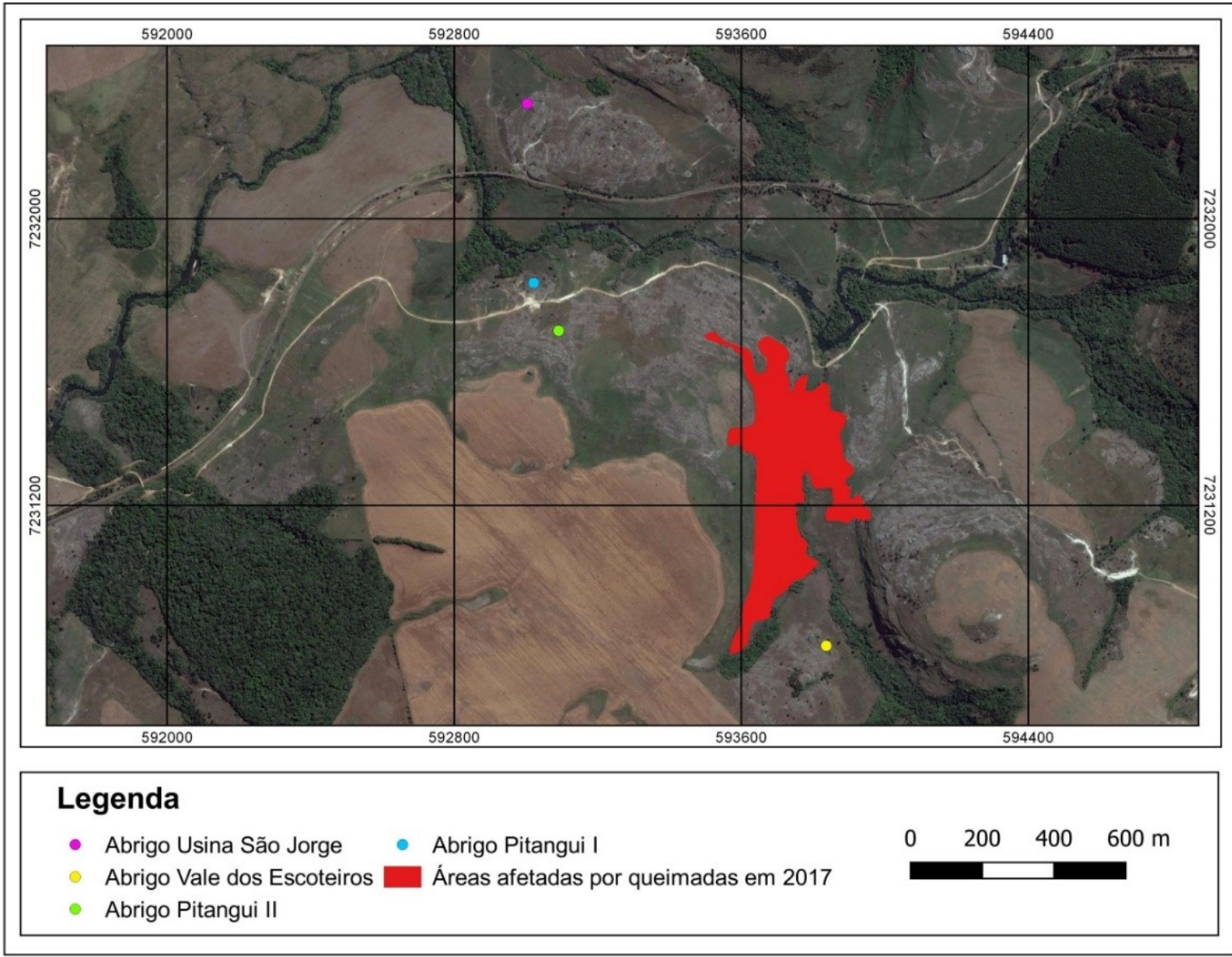

Figura 19 - Mapa da ocorrência de queimadas em setembro do ano de 2017. 


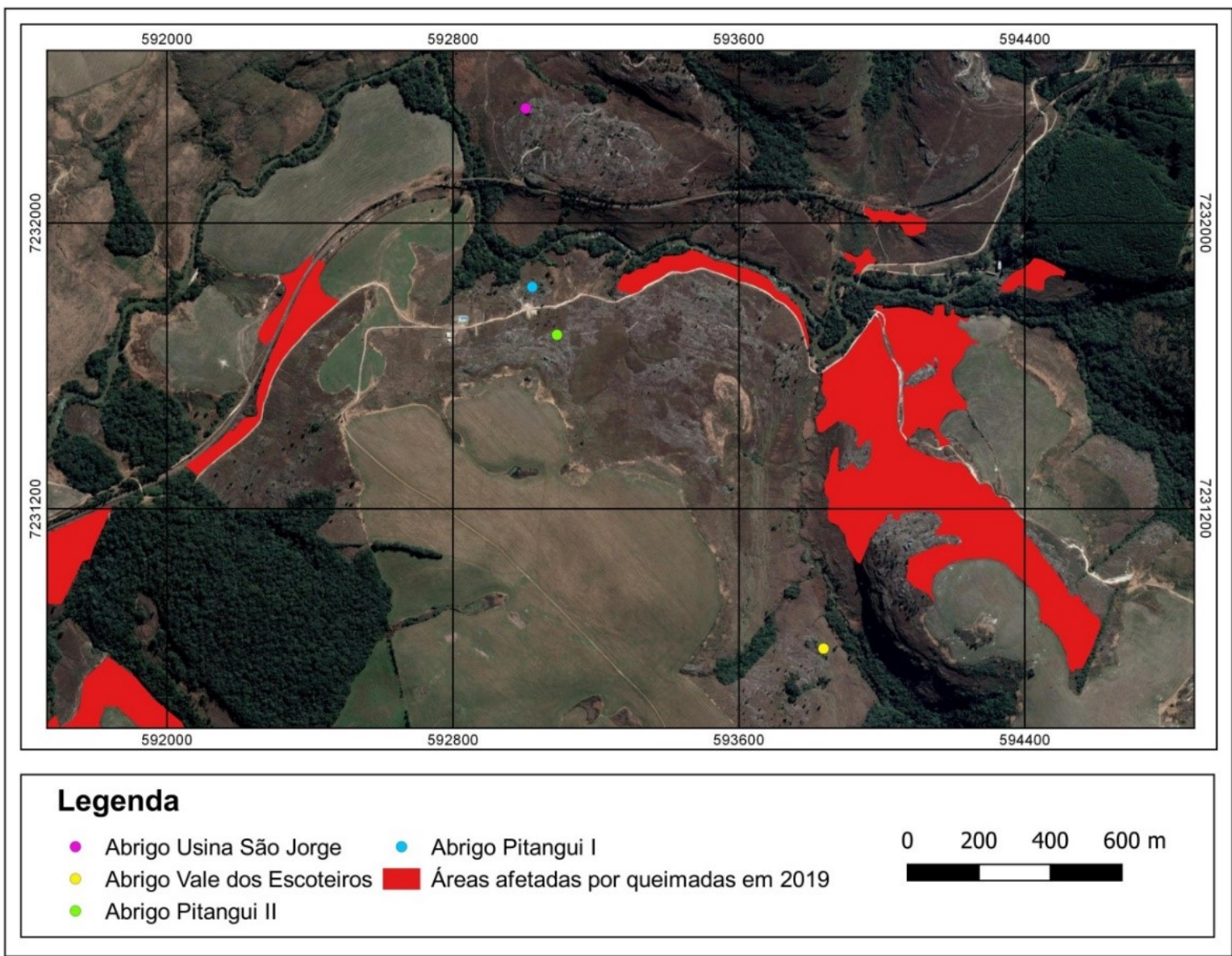

Figura 20 - Mapa da ocorrência de queimadas em julho do ano de 2019.

\section{DISCUSSÕES}

\subsection{Impactos antrópicos}

No entorno imediato dos abrigos ocorrem campos limpos e sujos e afloramentos rochosos. Contudo, nestes campos ocorre intensa contaminação de Pinus sp. e muito próximo destes locais há uso agrícola, sobretudo plantio de soja, estrada com trânsito de veículos, trilhas de caminhadas e de motocross, uso turístico, atividades estas que geram vários tipos de impactos negativos em escalas variadas de intensidade.

O Abrigo Usina São Jorge é o sítio mais impactado do vale do Rio Pitangui. Sobre suas pinturas rupestres há fuligem de fogo, provavelmente resultado de queimadas nos campos ou fogueiras produzidas por campistas que utilizaram a cavidade como abrigo temporário. Além disso, visitantes do local rabiscaram sobre as gravuras, impactos já relatados por Silva, Parellada e Melo (2007). Recentemente, vegetação nativa do entorno imediato do Abrigo Usina São Jorge foi suprimida para abertura e demarcação de uma trilha que fazia parte de um percurso de caminhada e corrida em ambiente natural. A destruição da vegetação nativa pode desencadear processos erosivos no solo e nos arenitos, podendo afetar a estabilidade dos abrigos, uma vez que na maioria dos casos as lapas são pouco espessas. 
As intensas atividades de motocross no vale do rio Pitangui tem gerado impactos significativos sobre a vegetação, solos e até mesmo em afloramentos rochosos. A circulação constante de motos em trilhas de distribuição difusa na paisagem gera, de maneira imediata, processos erosivos lineares de profundidade acentuada. Secundariamente, estes canais passam a constituir pontos que concentram o escoamento das águas pluviais, situação que acelera ainda mais os processos erosivos. O aumento gradativo do número de praticantes desta atividade tem proporcionado uma situação alarmante para esta área, pois associado com encostas íngremes e solos rasos de alta erodibilidade, o motocross tem gerado impactos ambientais significativos que podem ser facilmente observados na paisagem local. A proximidade das trilhas de motocross com os sítios arqueológicos, sobretudo o Abrigo Usina São Jorge, pode influenciar indiretamente e diretamente no estado de conservação das pinturas rupestres e da cavidade como um todo.

Um dos impactos mais marcantes nos sítios arqueológicos, e que gera grande risco à integridade das pinturas rupestres, são as queimadas. A presença de vegetação no interior das cavidades subterrâneas, mesmo que em baixa quantidade, serve como combustível para o fogo, possibilitando a formação de labaredas em pontos muito próximos ou diretamente sobre os registros arqueológicos.

No Abrigo Vale dos Escoteiros uma lasca de arenito foi extraída para construção de fogueira de acampamento e parte deste fragmento contém pinturas rupestres (figura 21). Isso mostra que o uso destes abrigos como pontos de acampamento acentuam o risco de impactos negativos sobre o patrimônio arqueológico.

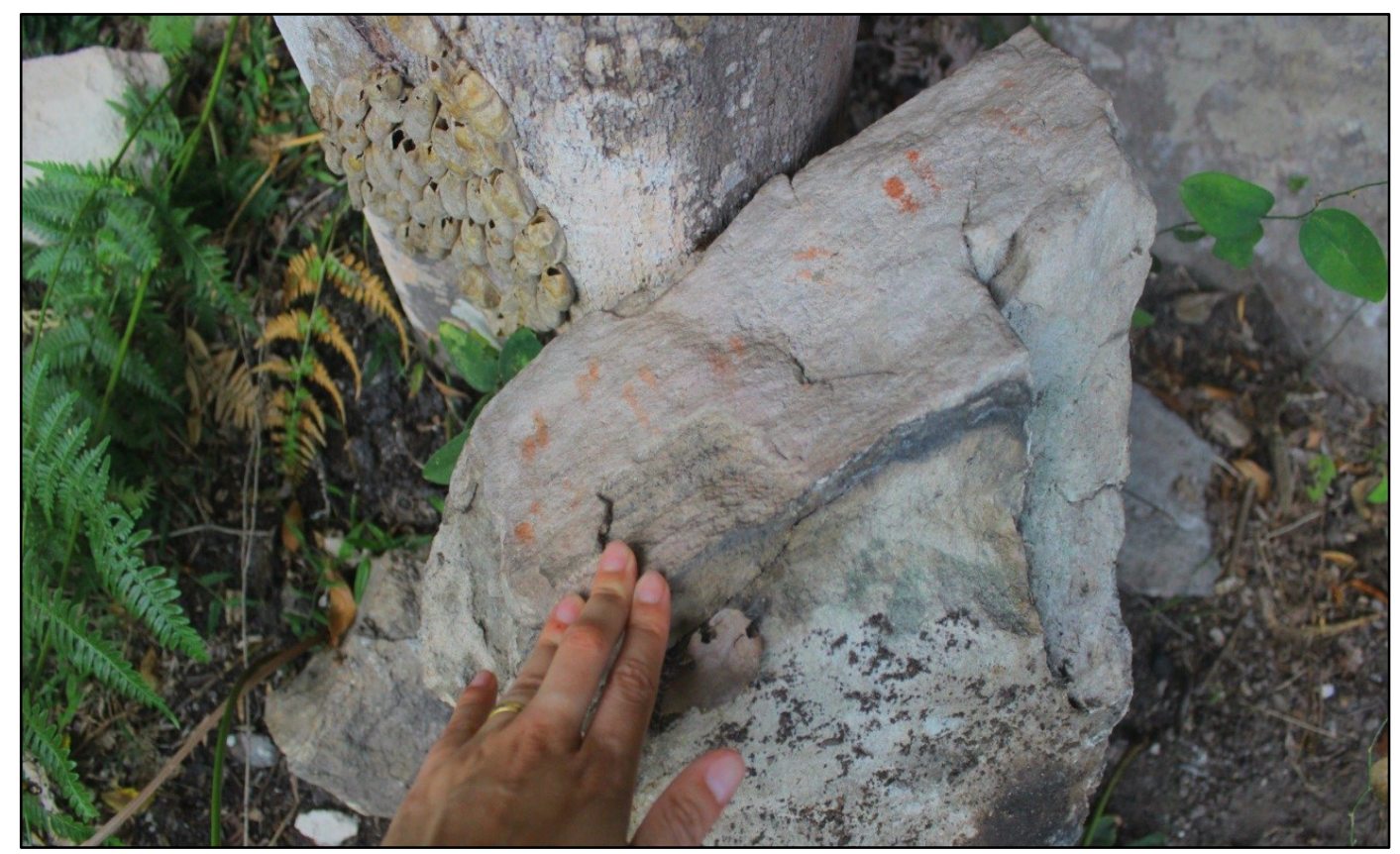

Figura 21 - Lasca de arenito contendo pinturas rupestres (pontilhados e traços) quebrada de parede e utilizada em fogueira no Abrigo Vale dos Escoteiros. 
Os impactos das queimadas e fogueiras sobre as pinturas rupestres estão relacionados principalmente com a ocorrência de fuligem que causa o escurecimento das paredes (LAGE et al., 2005). Assim como apontado anteriormente, as áreas de circulação de pessoas no vale do rio Pitangui constituem os locais mais susceptíveis para a ocorrência de queimadas, e como os abrigos são frequentemente visitados ou situam-se muito próximos a trechos de circulação de pessoas, o risco de impactos oriundo do fogo é ameaça constante ao patrimônio arqueológico em questão.

A dispersão de espécies arbóreas exóticas, sobretudo o Pinus sp., além de prejudicar a vegetação de campos nativos, em extinção em todos os Campos Gerais (PONTES et al., 2018), interfere na dinâmica hídrica, com o desaparecimento de nascentes, cursos hídricos e campos úmidos, situação que pode potencializar as queimadas e, consequentemente, afetar os abrigos. A agricultura mecanizada ainda não gera riscos aos sítios arqueológicos, contudo a expansão deste tipo de uso é preocupação constante.

O acesso sem controle de pessoas aos abrigos, seja qual for a finalidade, é um risco frequente à integridade do patrimônio arqueológico local. Pichações, rabiscos, piquetagem, abandono de lixo, quebra de rochas e produção de fogueira são as principais ações que visitantes descuidados ou mal intencionados podem realizar.

\subsection{A gestão dos sítios arqueológicos}

Conforme já mencionado, a área foco desta pesquisa situa-se na Área de Proteção Ambiental (APA) da Escarpa Devoniana e conforme o plano de manejo desta unidade de conservação, os sítios arqueológicos Abrigo Piatngui I, Abrigo Vale dos Escoteiros e Abrigo Usina São Jorge integram a Zona de Proteção 3 (ZP3) (MRS Estudos Ambientais, 2004). Este zoneamento ambiental define uma série de ações voltadas para o manejo e gestão deste patrimônio natural/cultural, incluindo atividades proibidas, objetivos de cada zona e as recomendações, conforme apresentado na tabela 2. Cabe destacar que em futuras revisões do Plano de Manejo da referida APA o Abrigo Pitangui II deve ser incluído na Zona de Proteção 3, a fim de incluí-lo em uma área desta unidade de conservação com maior proteção e restrição de uso.

É importante mencionar que uma Área de Proteção Ambiental está enquadrada na categoria de unidades de conservação de uso sustentável. Como sítios arqueológicos e cavidades subterrâneas são considerados bens da União, conforme a Constituição Federal do Brasil, deve-se reforçar que estes ambientes possuem regime de proteção diferenciado, sendo garantido a integridade destes locais. Assim, no que tange a gestão dos sítios arqueológicos, em um primeiro momento, instrumentos legais devem ser utilizados, ou criados se necessários, para garantir a efetiva proteção destes sítios arqueológicos. Através de ferramentas jurídicas será possível exigir e efetivar ações de gestão e manejo. 
Tabela 2: Considerações sobre a gestão na Zona de Proteção 3 (ZP3) da Área de Proteção Ambiental (APA) da Escarpa Devoniana, considerando os sítios arqueológicos.

\begin{tabular}{|c|c|c|}
\hline Atividades proibidas & Objetivos & Recomendações \\
\hline $\begin{array}{l}\text { - Retirada da vegetação de } \\
\text { entorno de áreas espeleológicas, } \\
\text { grutas, } \\
\text { sumidouros, } \\
\text { arqueolios } \\
\text { rupestres; } \\
\text { - Atividades durnas e abrigos } \\
\text { esportivas de alto impacto. }\end{array}$ & $\begin{array}{l}\text { - Proteção de abrigos e pinturas } \\
\text { rupestres; } \\
\text { - Preservação de áreas } \\
\text { Espeleológicas; } \\
\text { - Promover o turismo histórico } \\
\text { cultural; } \\
\text { - Fomentar e regulamentar } \\
\text { práticas sustentáveis de turismo. }\end{array}$ & $\begin{array}{l}\text { - Incentivo à criação de novas } \\
\text { Unidades de Conservação, em } \\
\text { especial na área da represa dos } \\
\text { Alagados e escarpa ao longo do } \\
\text { rio São Jorge; } \\
\text { - Levantar os abrigos rupestres } \\
\text { com potencial arqueológico; } \\
\text { - Incentivar formas de turismo } \\
\text { de baixo impacto e regulamentar } \\
\text { o turismo rural. }\end{array}$ \\
\hline
\end{tabular}

Fonte: Adaptado de MRS Estudos Ambientais (2004).

Visto as características, importâncias e problemáticas vinculadas aos sítios arqueológicos apresentados nesta pesquisa, são apontadas medidas para gestão deste patrimônio natural/cultural:

a) Criação/ampliação de áreas protegidas (principalmente unidades de conservação de proteção integral), sugerindo-se a implantação de Reservas Particulares do Patrimônio Natural (RPPN), por não necessitar desapropriação. Da mesma forma, o tombamento como patrimônio natural/cultural é outro meio de criar legalmente áreas protegidas, que demandam plano de gestão e manejo, por isso, entende-se que o tombamento da APA da Escarpa Devoniana deve ser incentivado por se tratar de um instrumento legal eficiente para a proteção do patrimônio arqueológico;

b) Delimitação e zoneamento da área de influência dos abrigos. Conforme apresentado nesta pesquisa, um raio mínimo de 250 metros deve ser levado em consideração, com base na legislação espeleológica. Entretanto, subdivisões de zoneamento devem ser estabelecidas, com definições de restrições de uso e cobertura do solo em diferentes intensidades;

c) Execução e estímulo às atividades e instrumentos de divulgação e educação patrimonial, incluindo visitas guiadas, aulas práticas para estudantes de diferentes níveis de formação, instalação de painéis interpretativos (seguindo princípios de mínimo impacto e locais apropriados de instalação), disseminação de informações sobre os sítios arqueológicos através de plataformas online, panfletos, palestras e visitas técnicas guiadas/monitoradas;

d) Realização de um plano de ação dos proprietários das áreas onde se situam os abrigos e proprietários vizinhos, visando orientar os usuários (turistas, caminhantes, motoqueiros, ciclistas, banhistas, pesquisadores, estudantes etc) sobre a existência dos sítios arqueológicos, os cuidados e exigências para garantir a preservação destes espaços;

e) Estímulo ao desenvolvimento de pesquisas científicas nos sítios arqueológicos e em suas áreas de influência;

f) Controle da circulação de motos e da abertura de novas trilhas de motocross nas áreas de influência direta das cavidades subterrâneas em questão;

g) Controle da circulação e da abertura de novas trilhas de trekking nas áreas de influência direta dos abrigos; 
h) Interdição de trilhas secundárias ou que estejam com significativo processo de erosão. Bem como, execução de medidas de controle dos processos erosivos nas trilhas de acesso existentes;

i) Controle das queimadas através da orientação dos usuários sobre a proibição de produção de fogueiras e descarte de bitucas de cigarro. Realização de aceiros, atalhadas ou sesmos no entorno dos abrigos, provocando a descontinuidade de material vegetal combustível, para evitar que o fogo de queimadas e incêndios se alastre (respeitando as leis ambientais);

j) Proibição do uso dos abrigos para acampamento, alimentação e produção de fogueiras;

k) Manutenção das características naturais da paisagem na área de influência de 250 metros dos sítios arqueológicos, com ações de recuperação de áreas degradadas;

1) Controle de espécies arbóreas exóticas invasoras (respeitando as leis ambientais);

m) Realização de visitas periódicas para vistorias, retirada de resíduos sólidos, manutenção de trilhas e demais ações e observações necessárias;

n) Permissão e estímulo de visitas turísticas aos abrigos apenas com o acompanhamento de guias de turismo credenciados ou pesquisadores com reconhecido conhecimento na área.

Além destas medidas, conforme apontado por IPHAN (2015) é necessário a realização de trabalhos especializados de conservação e restauro dos painéis danificados e resgate do material arqueológico, uma vez que além das pinturas rupestres, os abrigos apresentam potencial para ocorrência de artefatos líticos e cerâmicos.

\section{CONSIDERAÇÕES FINAIS}

A riqueza arqueológica dos Campos Gerais do Paraná, atrelada ao imenso patrimônio espeleológico (com potencial para novas descobertas), faz desta região um hot spot da arqueologia nacional. O vale do rio Pitangui, exatamente na porção média de seu curso, no município de Ponta Grossa, possui uma fração importante deste patrimônio. São quatro abrigos que apresentam pinturas rupestres das tradições Planalto e Geométrica.

Entretanto, há pelo menos mais de duas décadas, trabalhos científicos, entidades ambientalistas e pesquisadores têm denunciado a degradação nestes sítios arqueológicos, que aos poucos vem deteriorando e ocasionando a perda destes valiosos registros da arte dos povos primitivos. Mas nenhuma medida eficiente, para garantir a proteção destes ambientes e de seus conteúdos, foi adotada até agora.

Estas cavidades naturais subterrâneas seguem expostas a uma série de fatores e agentes causadores de graves impactos negativos, quase todos de caráter totalmente ou quase irreversível, incluindo queimadas, pichações sobre as pinturas rupestres e quebra proposital de painéis com gravuras. Além disso, a intensa visitação turística, processos erosivos causados por trilhas de motocross e descaracterização da vegetação nativa tem, em pesos diferentes de influência, afetado ou posto em risco a integridade física destes abrigos. 
É preciso uma união de esforços, entre pesquisadores, poder público e proprietários das áreas de ocorrência destes sítios arqueológicos para que este patrimônio natural/cultural seja preservado e mantido para as futuras gerações. A criação ou ampliação de áreas protegidas é uma ação importante (principalmente unidades de conservação de proteção integral ou tombamento), assim como a fiscalização. Mas, além disso, é fundamental que se tenha maior investimento em ações de divulgação e educação patrimonial, a fim de tornar este patrimônio conhecido pela população e, quem sabe, proporcionar o surgimento espontâneo de pertencimento e identidade com os Campos Gerais, com os sítios arqueológicos e com a história dos primeiros habitantes destas terras.

\section{AGRADECIMENTOS}

Os autores agradecem ao proprietário da Fazenda Rio Pitangui, Jeronymo Carraro Neto, pela liberação do acesso à área para elaboração deste estudo; e a Emanuele Rodrigues de Lima, pelas considerações adicionais ao texto.

\section{REFERÊNCIAS}

BLASI, O. Aspectos da arte pré-histórica no sul do Brasil. In: SYMPOSIUM INTERNATIONAL D'ART PRÉ-HISTORIQUE. 1970, Capo di Ponte. Actes... Capo di Ponte: Ed. Del Centro, 1970, p. 461-465.

BLASI, O. Cultura do índio pré-histórico. Vale do Iapó, Tibagi- PR. Arquivos do Museu Paranaense/ Nova Série Arqueologia, Curitiba, n. 6, 1972.

BLASI, O. Projeto de levantamento e cadastramento de sítios arqueológicos do segundo planalto paranaense. Relatório interno da Secretaria de Estado da Cultura do Paraná, Curitiba, 1991.

BRASIL. 2008. Decreto $\mathbf{n}^{\circ} \mathbf{6 . 6 4 0}$, de $\mathbf{7}$ de novembro de 2008 . Disponível em: http://www.planalto.gov.br/ccivil 03/_Ato2007-2010/2008/Decreto/D6640.htm. Acesso em: 27 mar. 2020.

CONAMA - Conselho Nacional de Meio Ambiente. Resolução CONAMA n 347, de 10 de setembro de 2004. Disponível em: https:/www.icmbio.gov.br/cecav/images/stories/downloads/Legislacao/ Res_CONAMA_347_2004.pdf. Acesso em: 23 mar. 2020.

HARMAN, J. DStretch: rock art digital enhancement. Disponível em: http://www.dstretch.com/. Acesso em: 09 mar. 2020.

ICMBio - Instituto Chico Mendes de Conservação da Biodiversidade. Informações sobre visitação em Unidades de Conservação - PARNA dos Campos Gerais, 2017. Disponível em: http://qv. icmbio.gov.br/QvAJAXZfc/opendoc2.htm?document=painel corporativo 6476.qvw\&host=Local\&ano nymous=true. Acesso em: 23 mar. 2020. 
IPHAN - Instituto do Patrimônio Histórico e Artístico Nacional. Visita técnica realizada no sítio arqueológico “Abrigo Usina São Jorge, município de Ponta Grossa/PR. Informação técnica $n^{\circ}$ 161/2015. 2015. 19p.

LAGE, M. C. S. M.; BORGES, J. F.; JÚNIOR, S. R. Sítios de registros rupestres: monitoramento e conservação. Mneme-Revista de Humanidades, v. 6, n. 13, p. 28-51, 2005.

MAACK, R. Notas preliminares sobre clima, solos e vegetação do Estado do Paraná. Arquivos de Biologia e Tecnologia, n. 2, p. 102-200, 1948.

MElO, M. S.; MORO, R. S.; GUIMARÃES, G. B. Patrimônio natural dos Campos Gerais do Paraná. Ponta Grossa: Editora UEPG, 2007.

MRS Estudos Ambientais. Plano de Manejo da Área de Proteção Ambiental da Escarpa Devoniana. Curitiba, junho de 2004. Disponível em: http://www.iap.pr.gov.br/arquivos/File/ Planos_de_Manejo/APA_Escarpa_Devoniana/1_APA_PM.pdf. Acesso em: 24 fev. 2020.

OLIVEIRA, F. C. P. Sítios arqueológicos com pinturas rupestres na região de Piraí da Serra, Campos Gerais do Paraná. In. SEMANA DE ANTROPOLOGIA: DESAFIOS DA ALTERIDADE, 4., 2014, Curitiba. Anais... Curitiba, 2014. p. 70-80.

PARANÁ PROJETOS. 2015. Relatório Estatístico Parque Estadual de Vila Velha. Disponível em: http://www.paranaprojetos.pr.gov.br/arquivos/File/Relatorio20152.pdf. Acesso em: 21 fev. 2020.

PARELLADA, C. I. Caracterização do patrimônio arqueológico do Parque Estadual Canyon do Guartelá. Curitiba: Museu Paranaense/IAP, 2000. 50p.

PEREIRA, E.; RUBIO, T. M.; BARBOSA, C. A. P. Documentação digital da arte rupestre: apresentação e avaliação do método em dois sítios de Monte Alegre, Amazônia, Brasil. Bol. Mus. Para. Emílio Goeldi. Cienc. Hum., Belém, v. 8, n. 3, p. 585-603, 2013.

PONTES, H. S.; MASSUQUETO, L. L.; GUIMARÃES, G. B.; ROCHA, C. H. O projeto de lei de redução da APA da Escarpa Devoniana: ameaças à proteção dos campos nativos e cavernas dos Campos Gerais do Paraná, Brasil. Terr@ Plural, v. 12, n. 2, p. 211-237, 2018.

PONTES, H. S. Patrimônio geológico cárstico em rochas areníticas e políticas públicas de geoconservação, com base em estudo de caso do município de Ponta Grossa (PR). 2020. 259 f.

Tese (Doutorado em Geologia Ambiental) - Universidade Federal do Paraná, Curitiba. 2020.

PROUS, A. Arqueologia brasileira. Brasília: Editora Universidade de Brasília, 1992. 607p.

SILVA, A.G.C. Pinturas rupestres do sítio arqueológico Abrigo Usina São Jorge, Ponta Grossa PR. 1999, 52 f. Monografia (Trabalho de graduação em Geografia) - Universidade Estadual de Ponta Grossa, Ponta Grossa, 1999.

SILVA, A. G. C.; PARELlADA, C. I.; MELO, M. S. Pinturas rupestres do sítio arqueológico abrigo Usina São Jorge, Ponta Grossa, Paraná. Publ. UEPG Exact Earth Sci., Agr. Sci. Eng., Ponta Grossa, v. 13, n. 1, p. 25-33, 2007. 